\title{
Pain and mortality: mechanisms for a relationship
}

DOI:

10.1097/j.pain.0000000000001193

\section{Document Version}

Accepted author manuscript

Link to publication record in Manchester Research Explorer

\section{Citation for published version (APA):}

Smith, D., Wilkie, R., Croft, P., \& Mcbeth, J. (2018). Pain and mortality: mechanisms for a relationship. Pain, 159(6), 1112-1118. https://doi.org/10.1097/j.pain.0000000000001193

\section{Published in:}

Pain

\section{Citing this paper}

Please note that where the full-text provided on Manchester Research Explorer is the Author Accepted Manuscript or Proof version this may differ from the final Published version. If citing, it is advised that you check and use the publisher's definitive version.

\section{General rights}

Copyright and moral rights for the publications made accessible in the Research Explorer are retained by the authors and/or other copyright owners and it is a condition of accessing publications that users recognise and abide by the legal requirements associated with these rights.

\section{Takedown policy}

If you believe that this document breaches copyright please refer to the University of Manchester's Takedown Procedures [http://man.ac.uk/04Y6Bo] or contact uml.scholarlycommunications@manchester.ac.uk providing relevant details, so we can investigate your claim.

\section{OPEN ACCESS}




\title{
Pain and mortality: mechanisms for a relationship
}

\author{
Diane Smith ${ }^{1}$, Ross Wilkie ${ }^{1}$, Peter Croft ${ }^{1}$, John McBeth ${ }^{2}$
}

1. Arthritis Research UK Primary Care Centre, Research Institute for Primary Care \& Health Sciences, Keele University,

Staffordshire

United Kingdom

2. Arthritis Research UK Centre for Epidemiology, Centre for Musculoskeletal Research, Institute of Inflammation and Repair Faculty of Medical and Human Sciences, Manchester Academic Health Sciences Centre,

The University of Manchester, United Kingdom

Pages: 21

Tables: 2

Figures: 1

Word Count: 3482

All correspondence relating to the paper should be addressed to Diane Smith diane.smith@mmu.ac.uk 


\section{Abstract}

Moderate to severe chronic pain affects one in five adults and its impact increases with age. People with chronic pain that interferes with their lives have an increased risk of mortality. Identifying how interfering chronic pain can lead to mortality may highlight potential intervention strategies. This study uses a novel approach to test whether lifestyle, health, social and psychological factors mediate the relationship between pain and mortality.

Survival analyses (Cox's proportional hazard modelling and a technique to assess mediation within survival models) were conducted on a large population study of adults aged $\geq 50$ years from the English Longitudinal Study of Ageing (ELSA) $(n=6324)$. Data collected at Wave 2 (2004) were used as baseline and follow-up was until 2012. The relationship between being "often troubled with pain" and mortality was examined. Lifestyle, health, social and psychological factors were tested as potential mediators.

The strongest mediating factors for the relationship between troubling pain and mortality were functional limitation (Hazard Ratio $1.31 ; 95 \% \mathrm{Cl}(1.20,1.39)$ ), symptoms preventing walking quarter of a mile $(1.45(1.35,1.58))$, physical inactivity $(1.14(1.10,1.20))$ and poor self-rated health $(1.32(1.23,1.41))$.

Mediators of the relationship between troubling pain and mortality provide targets for preventive health programmes. Interventions to improve general health, activity and function could improve long-term survival in patients with this clinical problem. 


\section{Introduction}

Moderate to severe pain affects one in five adults [29]. There is inconsistent evidence that mortality is higher in people with pain $[25,28]$, but emerging consistency that excess mortality might be restricted to those people with chronic pain that is interfering with everyday life [40]. This suggests that the impact of pain or associated characteristics of people with chronic pain may be the cause of excess mortality rather than the pain itself or the underlying cause of the pain $[2,25,28,43]$. We have investigated this hypothesis and present the results in this paper.

Mediation analysis enables an investigation of different pathways that could explain the effect of an exposure on an outcome. This paper presents novel analyses which tested if lifestyle, health, social and psychological factors were mediators of the relationship (i.e. lie on a pathway) between pain and mortality. These factors may explain the link between pain and mortality and may identify potential targets for interventions or populations who are particularly vulnerable and would benefit from prevention strategies. The proposed mediating factors were selected based on their theoretical plausibility as mediators and the availability of data to test this in the dataset used in this study [3$5,7,9,10,14,16,18-20,24,26,27,30,31,33,35,44]$ (see supplementary material). Mediation analysis has rarely been undertaken using survival models $[23,34,37]$. This study used a technique developed to perform mediation analysis within a survival model..

\section{Methods}

Design, study setting and population

Data from the English Longitudinal Study of Ageing (ELSA) were used. The data collection methods for this study are described in detail elsewhere [32]. Briefly, ELSA is a large scale 
longitudinal panel study of the health, economic and social circumstances of adults aged 50 years and over in England which began in 2002. Data collected at Wave 2 (2004) were used as baseline in this study. Complete data for pain, mortality, confounders and all potential mediators at baseline were available for 6324 participants (Figure 1). We have previously reported on the association between different phenotypes of pain and mortality using this dataset [40]. In this paper, we have selected our case definition to be chronic 'often troubling' pain for the mediation analysis.

(Figure 1 here)

\section{Outcome}

Information on vital status was available until the end of February 2012. Only year of death was available, therefore the time in the study was calculated in months from the date of interview until the $31^{\text {st }}$ December in the year the participant was known to have died (or $28^{\text {th }}$ February if they died in 2012).

\section{Exposure, mediators and covariates}

The exposure for this analysis was identified using a single item ("Are you often troubled by pain?" (yes/no) resulting in the dichotomous variable "often troubled with pain" versus "not often troubled with pain". The phrase "troubling pain" will be used throughout the paper for this phenotype. Lifestyle, health, social and psychological factors were tested as potential mediating variables of the relationship between pain and mortality; these were physical activity, smoking, alcohol consumption, self-reported health, functional limitation, symptoms preventing walking quarter of a mile (chest pain, fatigue/too tired, shortness of breath, tremor, pain in leg or foot, swelling in leg or foot, 
incontinence, seeing difficulty, hearing difficulty, confusion, difficulty concentrating, memory problems, unsteady on feet or balance problems, lightheaded or dizziness, fear of falling, anxiety or fear or other problem or symptom), social group membership, volunteer work, quality of life, depression and cognitive impairment (Supplementary table 1). Self-rated health may of course be a proxy for specific conditions that lead to early death but here is taken as a measure of an individual's aggregated reflection of the many dimensions that affect their health. Justification for the selection of the potential mediators is presented in the supplementary material. Age, sex, education and wealth were treated as potential confounders. Participants' educational qualifications were categorised to National Vocational Qualification (NVQ)4/5 or degree or equivalent, higher education below degree, NVQ3/Advanced level equivalent, NVQ2/Ordinary level equivalent, NVQ1/Certificate of Secondary education (CSE) or equivalent or foreign/other or no qualification. For wealth, net total non-pension wealth, was categorised using quintiles (highest to lowest). This measure of wealth has been found to be the strongest socioeconomic predictor of health in the ELSA sample [13]. Further information about the measurement of each variable including details of scales and psychometric properties (where appropriate) is presented in the supplementary material.

\section{Procedure}

This study used a technique developed to perform mediation analysis within survival analysis based on the counterfactual framework (see the explanation of this below); this required all mediators to be binary (Supplementary table 1). In time-to-event analysis, such as a Cox's proportional hazards model with a binary exposure and mediator, Lange and colleagues (2012) showed that a weighted Cox regression produces unbiased 
estimates for direct and indirect effects [23]. Within the counterfactual framework each participant is observed under one set of circumstances but consideration is also given to what would have happened to that participant under counterfactual circumstances (those that did not occur) [36]. This involves replication of analyses whereby, in the first instance the exposure takes the original value and in the replication, it takes the opposite or counterfactual value. Weights are derived from logistic regression of the binary mediator on the exposure and baseline confounders as follows:

$$
W_{i}^{c}=\frac{P\left(M=M_{i} \mid A=A_{i}^{*}, C=C_{i}\right)}{P\left(M=M_{i} \mid A=A_{i}, C=C_{i}\right)} .
$$

Where $A$ is the observed exposure of interest; $M$ is the mediator and $C$, a set of baseline confounders. * represents the counterfactual value(s)

Where the assumptions of proportional hazards and non-informative censoring are met, the weighted Cox regression model will give hazard ratios which are estimates for the direct and indirect effects. The product of these two hazard ratios provides the hazard ratio for the total effect. This is the approach used by Rochon et al., (2014) in their development of code for mediation analysis for the statistical package $\mathrm{R}$ and was the technique used to perform the analysis in this study (see supplementary material).

First, associations between the predictor exposure (troubling pain) and each mediating variable were examined using logistic regression to explain the direction of any mediating effect (e.g. a negative association (odds ratio less than 1 ) between troubling pain and greater physical activity means the hazard ratio (above 1 ) of the indirect effect refers to an increased risk of mortality as a result of pain and lower levels of physical activity). All associations between troubling pain and potential mediators are presented as odds ratios 
(OR) with $95 \%$ confidence intervals. All analyses were adjusted for putative confounders (age, sex, education and wealth). Results of the mediation analyses (carried out using the technique described above) are presented as hazard ratios (HR) for the direct, indirect and total effects with associated $95 \%$ confidence intervals. Mediation was indicated by the presence of an indirect effect. The descriptive analysis was performed using Stata version 13 and the survival and mediation analyses were carried out using R. Confidence intervals were calculated using bootstrapping [37].

\section{Results}

Of the 6324 included participants, $35.9 \%$ of the sample reported troubling pain (Table 1). The median age was 63 years and $55 \%$ were female. The length of time in the study for those who died $(n=764(12.1 \%))$ ranged from 0 months to 90 months from the date of interview, with a mean survival time of 54.1 months (SD 24.7). Within 12 months of the interview date forty deaths (5.2\% of all deaths) occurred.

Lifestyle factors

Troubling pain was associated with lower levels of physical activity and low alcohol consumption, but was not associated with smoking. The relationship between troubling pain and mortality was mediated by physical inactivity and low alcohol consumption but not smoking (e.g. for physical activity theOR $0.34(95 \% \mathrm{Cl} 0.30,0.39)$ for association between troubling pain and moderate/vigorous physical activity indicates that the indirect effect of $\mathrm{HR} 1.14,(95 \% \mathrm{Cl} 1.10,1.20)$ is a result of an association between pain and physical inactivity) (Table 2). 
Health factors

All health factors (poorer self-reported health, functional limitation, and symptoms preventing walking quarter of a mile) were each associated with troubling pain and mediated the relationship between troubling pain and mortality (e.g. association of troubling pain with good to excellent health; OR $0.18,95 \% \mathrm{Cl} 0.16,0.21$ and indirect effect of self-rated health; HR 1.32, 95\% Cl 1.23, 1.41 indicates the relationship between pain and mortality is mediated by poor self-reported health) (Table 2).

\section{Social factors}

Low social group membership and not participating in volunteer work were associated with troubling pain and both of these factors mediated the relationship between troubling pain and mortality (e.g. association between troubling pain and membership of 2 or more social groups; OR $0.86,95 \% \mathrm{Cl} 0.77,0.96$ and indirect effect of social group membership; HR 1.01, 95\% $\mathrm{Cl} 1.00,1.02$ indicates the observed mediating effect is due to low social group membership) (Table 2).

\section{Psychological factors}

Troubling pain was associated with lower quality of life (control, autonomy, pleasure and self-realisation), depression and cognitive impairment. There were mediating effects of all psychological factors (e.g. association between troubling pain and CESD score $>4$ (depressed); OR 2.62, 95\% Cl 2.33, 2.95 and indirect effect of depression; $\mathrm{HR} 1.09,95 \% \mathrm{Cl}$ 1.05, 1.12). (Table 2).

\section{Discussion}

Summary of findings 
There is increasing evidence that pain that interferes with daily activities is associated with premature mortality and the large number of adults with such pain justifies action to identify how to reduce this impact. This study identified health, lifestyle, social and psychological factors that explained the relationship between troubling pain and premature mortality; this indicates that there are a number of potential targets to reduce mortality for people with pain.

The most powerful explanatory factors for the relationship between troubling pain and mortality in the current study, indicated by a larger indirect effect and a greater reduction in direct effects [21], were those which measured physical limitation and inactivity. The precise mechanisms could be multiple, since physical inactivity is linked to a number of chronic diseases (e.g. cardiovascular disease, cancer, diabetes, hypertension, obesity, osteoporosis and depression) [45], all of which confer increased mortality risk. Interventions to increase physical activity in people with pain where possible would help to reduce their risk of mortality by contributing to weight control and maintenance of function of body systems [45], in addition to reducing the persistence of pain and improving pain related function [11].

Measures of functional limitation resulted in the strongest mediating effects (i.e. resulted in the largest hazard ratios for indirect effects). This is consistent with previous studies reporting reduced functional ability in people with pain [46] and associations between functional impairment and mortality [39]. Self-reported assessments of functional impairment measure perceived limitations in physical capacity rather than the amount of physical activity [42], but the former has inevitable consequences for the latter. Functional limitation will lead to physical inactivity and this emphasises the importance of 
physical capacity and managing functional limitation for people in pain through interventions such as physiotherapy, exercise classes and psychological therapies that address barriers to physical activity [42].

\section{Comparison with other studies}

This was the first study to investigate potential mediators of a relationship between pain and mortality and one of only a small number of studies that have examined mediating effects within survival analysis. Andersson (2009) reported an association between widespread pain and mortality that was explained by lifestyle factors; specifically smoking, physical activity, stress and sleep disorders [2]. However, Andersson's study did not test pathways from pain to mortality; factors were adjusted for as confounders within survival analysis.

There was no mediating effect of alcohol consumption in the current study. However, the association between pain and reduced alcohol intake observed in the current study is consistent with previous research $[8,27]$ and suggests low alcohol consumption may be a proxy for poor health. The symptoms older adults experience, their associated medication use and possibly a subsequent reduction in social activities where alcohol is consumed [8] may explain why pain is associated with lower alcohol consumption.

Smoking was not a mediating factor in the current study. The dichotomy of current smoker/non-smoker used in this analysis is a limitation as it only measures current smoking status. Mortality from smoking is linked to the number of cigarettes smoked and to when people stopped [15] and this comparison between never/ previous smokers and current smokers does not provide an account of this. It may be more likely that a current 
smoker with pain may increase the amount they smoke as a way to cope with their pain [14]; however this hypothesis could not be tested in this study. It was also not possible to test the direction of the relationship between pain and smoking. Pain may be associated with not being a current smoker as a result of other health conditions prompting an individual to quit, and those other health conditions may account for the increased risk of mortality in those people.

\section{Strengths and limitations}

A strength of this study is that it was longitudinal with data collection on pain and potential mediators collected in advance of the outcome of interest (in this case death). Furthermore, the study and data collection came from a general population cohort unaffected by selection with respect to the hypotheses investigated in this paper. In particular the study was able to specifically examine potential mechanisms for a relationship between pain and mortality. A new technique was used to estimate the extent of mediation by the proposed mediators within survival analysis accounting for time. Key targets were identified to reduce mortality in older adults with pain.

This is the first time, within a survival model of pain and mortality, that mediation has been examined. A strength of the study was that the data variables could be dichotomised to enable this mediation analysis to be undertaken. However, this need for binary variables brings with it some limitations, notably the potential loss of precision and misclassification. This also prevented examination for trends in the extent of mediation with increasing levels of exposures $[1,41]$. However, analyses to compare moderate to severe pain with mild/not often troubled and severe pain with moderate/mild/not often 
troubled (see supplementary table 2.) revealed the patterns of mediation resulting from this were not dissimilar to the pain dichotomy originally used.

For some of the mediating factors the hazard ratio for the indirect effect is close to 1.00 . The loss of information as a result of dichotomising reduces confidence these variables are true mediators of the relationship between pain and mortality. In addition, consideration of multiple hypotheses simultaneously increased the likelihood of a type 1 error [6] and it was not possible to correct for this here.

A single mediator cannot fully explain a relationship between an exposure and outcome but testing individual mediators helps to determine which different factors may contribute to a more complex relationship. In the analysis undertaken in this study, pain described as "often troubling" continued to have a direct effect on mortality in some of the mediation models. This description of pain may capture a number of different ways pain impacts on an individual's life and the individual mediators examined account for only some of this impact.

There were limitations in the way some of the proposed mediators were measured. For example, for some of the symptoms preventing walking quarter of a mile, the pathway between predictor and mediator may are uncertain. This variable included individual symptoms that were unlikely to be a result of pain i.e. seeing or hearing difficulties. The inclusion of these items reduces clarity in mediating effect of this composite variable.

Additionally, it must be acknowledged that some causes of pain are more likely to be associated with mortality and more likely to interfere with life than others, and that this might produce a spurious association between pain interference and mortality. In order to address this, stratified analyses of participants with and without comorbidities were 
undertaken (see supplementary table 3). Indirect pathways from pain to mortality were observed in participants both with and without comorbidity indicating that interventions to target identified mediating factors are important to reduce mortality risk in everyone with pain, not just in those with comorbidity.

Measures which capture broad constructs such as general health and quality of life may not be direct targets for intervention but would be influenced by the management of other targets. For example, improvements in self-rated health are likely to be dependent on a broad range of factors. Interventions to improve the individual lifestyle, health, social and psychological factors indicated as mediators in this study are likely to subsequently result in improved quality of life/ self-rated health in addition to reduced mortality risk.

As in all questionnaire studies, self-report information may be influenced by recall bias, however this is the best method for obtaining information on pain and some psychosocial factors (e.g. quality of life). Information obtained by self-report is limited by inaccuracies due to problems with recall and with differing interpretations of questions which affect face validity. A particular example of this is with the report of physical activity levels. A high proportion of the sample (31\%) reported engaging in vigorous activities at least once a week. This could be a result of information bias (one person's idea of what constitutes vigorous activity may differ greatly from another's), recall bias (inaccurate recollection of activity) or response bias (questionnaire responders provide selectively more favourable answers (e.g. higher activity levels)) [12]. Misclassification of activity levels in the current study was therefore quite likely but the impact of this (and other) misclassification would tend to result in underestimates of the real size of any associations observed). 
Whilst the ELSA sample is generalisable to the national population of England aged 50 and over, missing data introduced the potential for selection bias. However, we have previously reported the impact of this to be minimal for this sample [40]. The proportion of the study population that were vigorously active (31\%) can be considered as high. The ELSA sample is an active group of older adults (as has been reported elsewhere [22]) which may limit generalisability.

Mediation analysis is carried out in an attempt to elucidate mechanisms for relationships between exposures and outcomes. Although the study was longitudinal with respect to the main outcome (death), it is a potential limitation that the variables investigated for their potential mediating role in the pathway between pain and death were not measured at a later date than the pain variable. Often, as in this study, mediators are considered individually and have been measured at the same time as the exposure. Causal inference based on observational data, particularly cross-sectional data should be made with caution [17]. Mediator analyses are based on theoretical events or processes that unfold over time and the sequence is determined by what is theoretically plausible. There are often multiple ways of defining the relationships between the variables [38]. The pathways between pain and mortality identified by the current study are useful for suggesting potential targets for intervention but the true complexity of relationships and processes can never be modelled exactly using statistical techniques.

Implications for research and practice

This study has identified a number of factors that explain the relationship between troubling pain and mortality and are potential targets for reducing the risk of death. 
Further development of the technique used to undertake the mediation analysis would allow for a more detailed and precise investigation of mediating factors, particularly with categorical and continuous variables. This would provide a more accurate representation of the relationships investigated in this study. However, this study has provided a strong indication that factors affecting mobility, physical activity and perception of health are important mediators of the relationship between pain and mortality. Interventions to increase physical function, physical activity and perceived general health may help to reduce the risk of death in those with pain.

\section{Acknowledgements}

ELSA data were made available through the UK Data Archive (UKDA). ELSA was developed by a team of researchers based at the NatCen Social Research, University College London and the Institute for Fiscal Studies. The data were collected by NatCen Social Research. The funding is provided by the National Institute of Aging in the United States, and a consortium of UK government departments co-ordinated by the Office for National Statistics. The developers and funders of ELSA and the Archive do not bear any responsibility for the analyses or interpretations presented here.

Additional pain phenotype mediation analyses were conducted by Simran.......

There are no conflicts of interest.

The authors' work was supported by Arthritis Research UK Primary Care Centre, Primary Care Sciences, Keele University. 


\section{References}

[1] Altman DG, Royston P. The cost of dichotomising continuous variables. BMJ 2006;332:1080.

[2] Andersson HI. Increased mortality among individuals with chronic widespread pain relates to lifestyle factors: a prospective population-based study. Disabil. Rehabil. 2009;31:1980-7. doi:10.3109/09638280902874154.

[3] Ang DC, Kroenke K, McHorney C a. Impact of pain severity and location on healthrelated quality of life. Rheumatol. Int. 2006;26:567-72. doi:10.1007/s00296-0050025-z.

[4] Bair M, Wu J. Association of Depression and Anxiety Alone and in Combination with Chronic Musculoskeletal Pain in Primary Care Patients. Psychosom. ... 2008;70:890897. doi:10.1097/PSY.0b013e318185c510.Association.

[5] Bassuk SS, Wypij D, Berkman LF. Cognitive impairment and mortality in the community-dwelling elderly. Am. J. Epidemiol. 2000;151:676-88. Available: http://www.ncbi.nlm.nih.gov/pubmed/10752795.

[6] Bender R, Lange S. Adjusting for multiple testing - When and how? J. Clin. Epidemiol. 2001;54:343-349.

[7] Breivik H, Eisenberg E, O'Brien T. The individual and societal burden of chronic pain in Europe: the case for strategic prioritisation and action to improve knowledge and availability of appropriate care. BMC Public Health 2013.

[8] Brennan P, Schutte K, SooHoo S, Moos R. Painful Medical Conditions and Alcohol Use: A Prospective Study among Older Adults. Pain Med. 2011:1049-1059.

Available: http://onlinelibrary.wiley.com/doi/10.1111/j.15264637.2011.01156.x/full. Accessed 29 Aug 2012.

[9] Chou K-L. Reciprocal relationship between pain and depression in older adults: evidence from the English Longitudinal Study of Ageing. J. Affect. Disord. 2007;102:115-23. doi:10.1016/j.jad.2006.12.013.

[10] Cooper R, Kuh D, Hardy R, Mortality Review Group. Objectively measured physical capability levels and mortality: systematic review and meta-analysis. Bmj 2010;341:c4467-c4467. doi:10.1136/bmj.c4467.

[11] Croft P, Blyth FM, van der Windt D. Chronic Pain Epidemiology. 2010. doi:10.1093/acprof:oso/9780199235766.001.0001.

[12] Delgado-Rodríguez M, Llorca J. Bias. J. Epidemiol. Community Health 2004;58:63541. doi:10.1136/jech.2003.008466.

[13] Demakakos P, Nazroo J, Breeze E, Marmot M. Socioeconomic status and health: The role of subjective social status. Soc. Sci. Med. 2008;67:330-340.

[14] Ditre JW, Brandon TH. Pain as a motivator of smoking: effects of pain induction on smoking urge and behavior. J. Abnorm. Psychol. 2008;117:467-72. doi:10.1037/0021-843X.117.2.467.

[15] Doll R, Peto R, Boreham J, Sutherland I. Mortality in relation to smoking: 50 years' 
observations on male British doctors. BMJ 2004;328:1519. doi:10.1136/bmj.38142.554479.AE.

[16] Glass TA, de Leon CM, Marottoli RA, Berkman LF. Population based study of social and productive activities as predictors of survival among elderly Americans. BMJ 1999;319:478-483.

[17] Grimes D, Schulz K. Bias and causal associations in observational research. Lancet 2002;359:248-252. Available: http://chnri.com/resources/1. Learning Resource Material/Epidemiology/Epidemiology/Association/Papers/Bias and causal associations in observational research.pdf. Accessed 18 Feb 2013.

[18] Gureje O, Korff M Von. Persistent pain and well-being. JAMA J. ... 1998;280:147152. Available: http://jama.ama-assn.org/content/280/2/147.short. Accessed 12 Oct 2012.

[19] Idler EL, Benyamini Y. Self-rated health and mortality: a review of twenty-seven community studies. J. Health Soc. Behav. 1997;38:21-37. Available: http://www.ncbi.nlm.nih.gov/pubmed/9097506.

[20] Kaplan MS, Berthelot J-M, Feeny D, McFarland BH, Khan S, Orpana H. The predictive validity of health-related quality of life measures: mortality in a longitudinal population-based study. Qual. Life Res. 2007;16:1539-1546. doi:10.1007/s11136-007-9256-7.

[21] Keele L. Causal Mediation Analysis: Warning! Assumptions Ahead. Am. J. Eval. 2015. doi:10.1177/1098214015594689.

[22] Lang I a, Guralnik JM, Melzer D. Physical activity in middle-aged adults reduces risks of functional impairment independent of its effect on weight. J. Am. Geriatr. Soc. 2007;55:1836-41. doi:10.1111/j.1532-5415.2007.01426.x.

[23] Lange T, Vansteelandt S, Bekaert M. A simple unified approach for estimating natural direct and indirect effects. Am. J. Epidemiol. 2012;176:190-195.

[24] Leveille SG, Zhang Y, McMullen W, Kelly-Hayes M, Felson DT. Sex differences in musculoskeletal pain in older adults. Pain 2005;116:332-8. doi:10.1016/j.pain.2005.05.002.

[25] Macfarlane GJ, McBeth J, Silman AJ. Widespread body pain and mortality: prospective population based study. Bmj 2001;323:1-5.

[26] Mapes DL, Lopes AA, Satayathum S, McCullough KP, Goodkin DA, Locatelli F, Fukuhara S, Young EW, Kurokawa K, Saito A, Bommer J, Wolfe RA, Held PJ, Port FK. Health-related quality of life as a predictor of mortality and hospitalization: The dialysis outcomes and practice patterns study (DOPPS). Kidney Int. 2003;64:339349.

[27] McBeth J, Nicholl B. Chronic widespread pain predicts physical inactivity: Results from the prospective EPIFUND study. ... J. Pain 2010;14:972-979. Available: http://onlinelibrary.wiley.com/doi/10.1016/j.ejpain.2010.03.005/full. Accessed 20 Aug 2012.

[28] McBeth J, Symmons DP, Silman a J, Allison T, Webb R, Brammah T, Macfarlane GJ. Musculoskeletal pain is associated with a long-term increased risk of cancer and cardiovascular-related mortality. Rheumatology (Oxford). 2009;48:74-7. 
doi:10.1093/rheumatology/ken424.

[29] Moore RA, Derry S, Taylor RS, Straube S, Phillips CJ. The costs and consequences of adequately managed chronic non-cancer pain and chronic neuropathic pain. Pain Pract. 2014;14:79-94. doi:10.1111/papr.12050.

[30] Moriarty O, McGuire B, Finn D. The effect of pain on cognitive function: a review of clinical and preclinical research. Prog. Neurobiol. 2011;93:385-404. doi:10.1016/j.pneurobio.2011.01.002.

[31] Mykletun A, Bjerkeset O, Overland S, Prince M, Dewey M, Stewart R. Levels of anxiety and depression as predictors of mortality: the HUNT study. Br. J. Psychiatry 2009;195:118-25. doi:10.1192/bjp.bp.108.054866.

[32] NatCen Social Research. English Longitudinal Study of Ageing (ELSA) Waves 1 to 6. User guide to the core datasets. 2014 p.

[33] Neogi T. The epidemiology and impact of pain in osteoarthritis. Osteoarthr. Cartil. 2013;21:1145-1153.

[34] Preacher KJ. Advances in Mediation Analysis : A Survey and Synthesis of New Developments. Annu. Rev. Psychol. 2015;66:825-52.

[35] Reyes-Gibby CC, Aday L, Cleeland C. Impact of pain on self-rated health in the community-dwelling older adults. Pain 2002;95:75-82. Available: http://www.ncbi.nlm.nih.gov/pubmed/11790469.

[36] Robins JM, Greenland S. Identifiability and exchangeability for direct and indirect effects. Epidemiology 1992;3:143-155.

[37] Rochon J, du Bois A, Lange T. Mediation analysis of the relationship between institutional research activity and patient survival. BMC Med. Res. Methodol. 2014.

[38] Roe $R$ a. What is wrong with mediators and moderators. Eur. Heal. Psychol. 2012;14:4-10. Available: http://www.ehps.net/ehp/issues/2012/v14iss1_March2012/EHP_March_2012.pdf \#page=5.

[39] Scott W, Macera C. Functional health status as a predictor of mortality in men and women over 65. J. Clin. ... 1997;50:291-296. Available: http://www.sciencedirect.com/science/article/pii/S0895435696003654. Accessed 1 Nov 2013.

[40] Smith D, Wilkie R, Croft P, McBeth J. Pain and mortality in older adults: The influence of pain phenotype. Arthritis Care Res. (Hoboken). 2017. doi:10.1002/acr.23268.

[41] Streiner DL. Breaking up is hard to do: The heartbreak of dichotomizing continuous data. Can. J. Psychiatry 2002;47:262-266.

[42] Tang NKY, McBeth J, Jordan KP, Blagojevic-Bucknall M, Croft P, Wilkie R. Impact of musculoskeletal pain on insomnia onset: a prospective cohort study. Rheumatology 2014;54:248-256. doi:10.1093/rheumatology/keu283.

[43] Torrance N, Elliott A. Severe chronic pain is associated with increased 10 year mortality. A cohort record linkage study. Eur. J. Pain 2010;14:380-386. Available: http://onlinelibrary.wiley.com/doi/10.1016/j.ejpain.2009.07.006/full. Accessed 29 
Aug 2012.

[44] Tüzün EH. Quality of life in chronic musculoskeletal pain. Best Pract. Res. Clin. Rheumatol. 2007;21:567-79. doi:10.1016/j.berh.2007.03.001.

[45] Warburton DER, Nicol CW, Bredin SSD. Health benefits of physical activity: the evidence. CMAJ 2006;174:801-9. doi:10.1503/cmaj.051351.

[46] Weiner DK, Haggerty CL, Kritchevsky SB. How Does Low Back Pain Impact Physical Function in Independent, Well-Functioning Older Adults ? Evidence from. Pain Med. 2003;4:1-11. 
List of figures

Figure 1. Number and proportion of participants with missing data in the ELSA sample 


\begin{tabular}{|c|c|c|c|}
\hline \multirow[t]{3}{*}{$\begin{array}{c}\text { Total number of } \\
\text { participants at baseline }\end{array}$} & Variable & $\begin{array}{c}\text { n with missing } \\
\text { data }\end{array}$ & $\begin{array}{l}\text { Proportion of } \\
\text { total with } \\
\text { missing values }\end{array}$ \\
\hline & $\operatorname{Sex}(n=9432)$ & 0 & $0.0 \%$ \\
\hline & Pain $(n=9424)$ & 8 & $0.1 \%$ \\
\hline \multirow{3}{*}{$11-5432$} & Education $(n=9415)$ & 17 & $0.2 \%$ \\
\hline & $\begin{array}{l}\text { Excluded as age (below } \\
50 \text { ) }\end{array}$ & 238 & $2.5 \%$ \\
\hline & Mortality $(n=8799)$ & 633 & $6.7 \%$ \\
\hline \multirow{2}{*}{$\sqrt{2}$} & Wealth $(n=8661)$ & 771 & $8.2 \%$ \\
\hline & Cumulative total & 860 & $9.1 \%$ \\
\hline \multirow{4}{*}{$\begin{array}{l}\text { Participants at baseline with } \\
\text { complete predictor, outcome } \\
\text { and confounder data }\end{array}$} & Variable & $\begin{array}{c}\text { n with missing } \\
\text { data }\end{array}$ & $\begin{array}{l}\text { Proportion of } \\
8572 \text { with } \\
\text { missing values }\end{array}$ \\
\hline & Physical activity & 0 & $0.0 \%$ \\
\hline & $\begin{array}{l}\text { Symptoms preventing } \\
\text { walking) }\end{array}$ & 0 & $0.0 \%$ \\
\hline & $\begin{array}{l}\text { Functional limitation } \\
\text { (ADL/IADL difficulties) }\end{array}$ & 1 & $0.0 \%$ \\
\hline \multirow{4}{*}{ 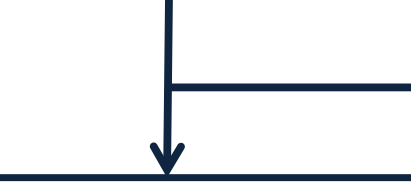 } & Smoking & 2 & $0.0 \%$ \\
\hline & Volunteer work & 2 & $0.0 \%$ \\
\hline & Self-rated health & 5 & $0.1 \%$ \\
\hline & Depression (CESD) & 19 & $0.2 \%$ \\
\hline \multirow{5}{*}{$\begin{array}{l}\text { Complete data at baseline } \\
\text { (predictor, outcome, } \\
\text { confounders and all mediators) } \\
\text { n = } 6324\end{array}$} & Cognitive impairment & 50 & $0.6 \%$ \\
\hline & Alcohol & 1012 & $11.8 \%$ \\
\hline & Social group membership & 1370 & $16.0 \%$ \\
\hline & Quality of life (CASP 19) & 1758 & $20.5 \%$ \\
\hline & Cumulative total & 2248 & $26.2 \%$ \\
\hline
\end{tabular}

Figure 1. 


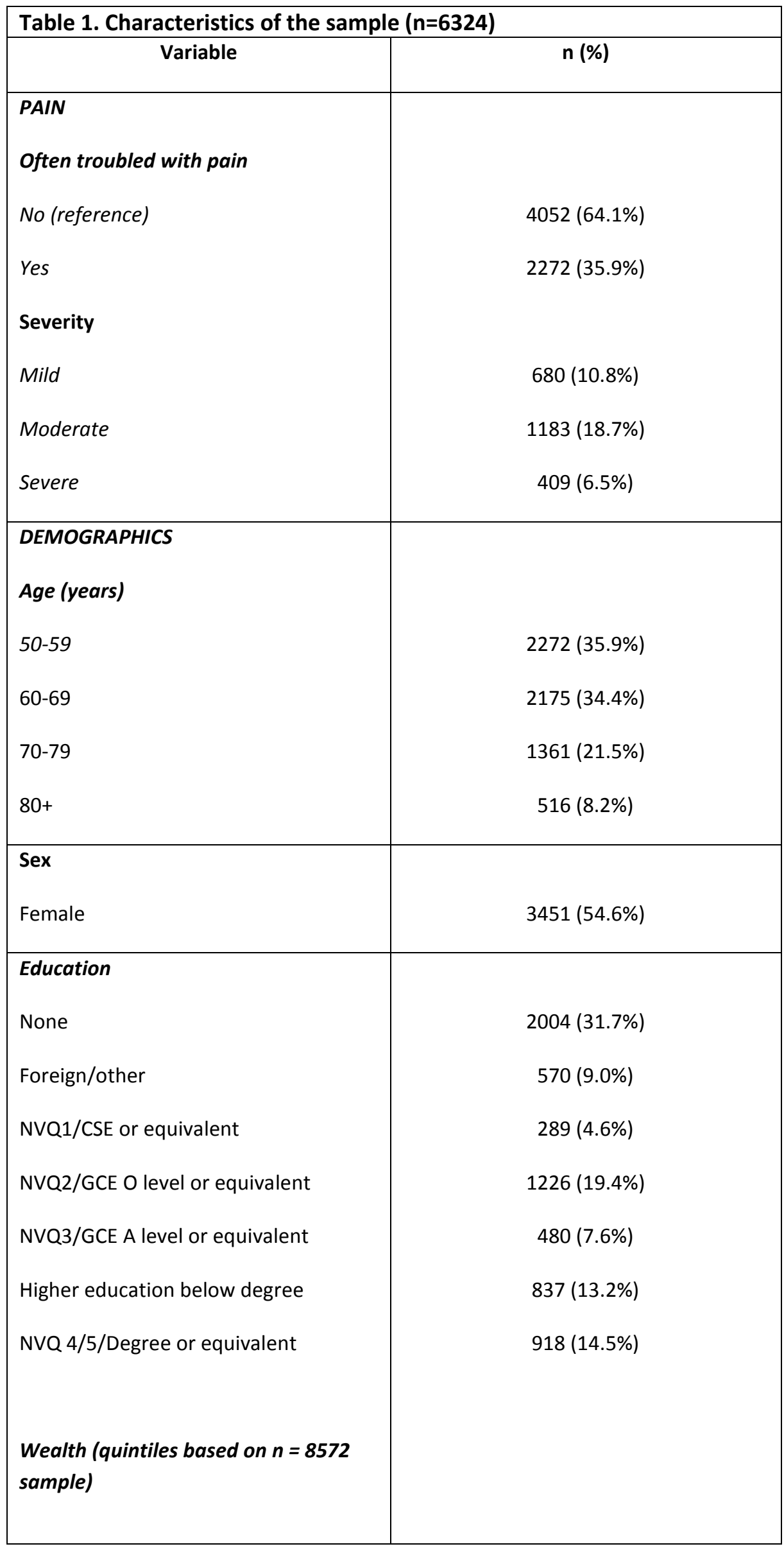




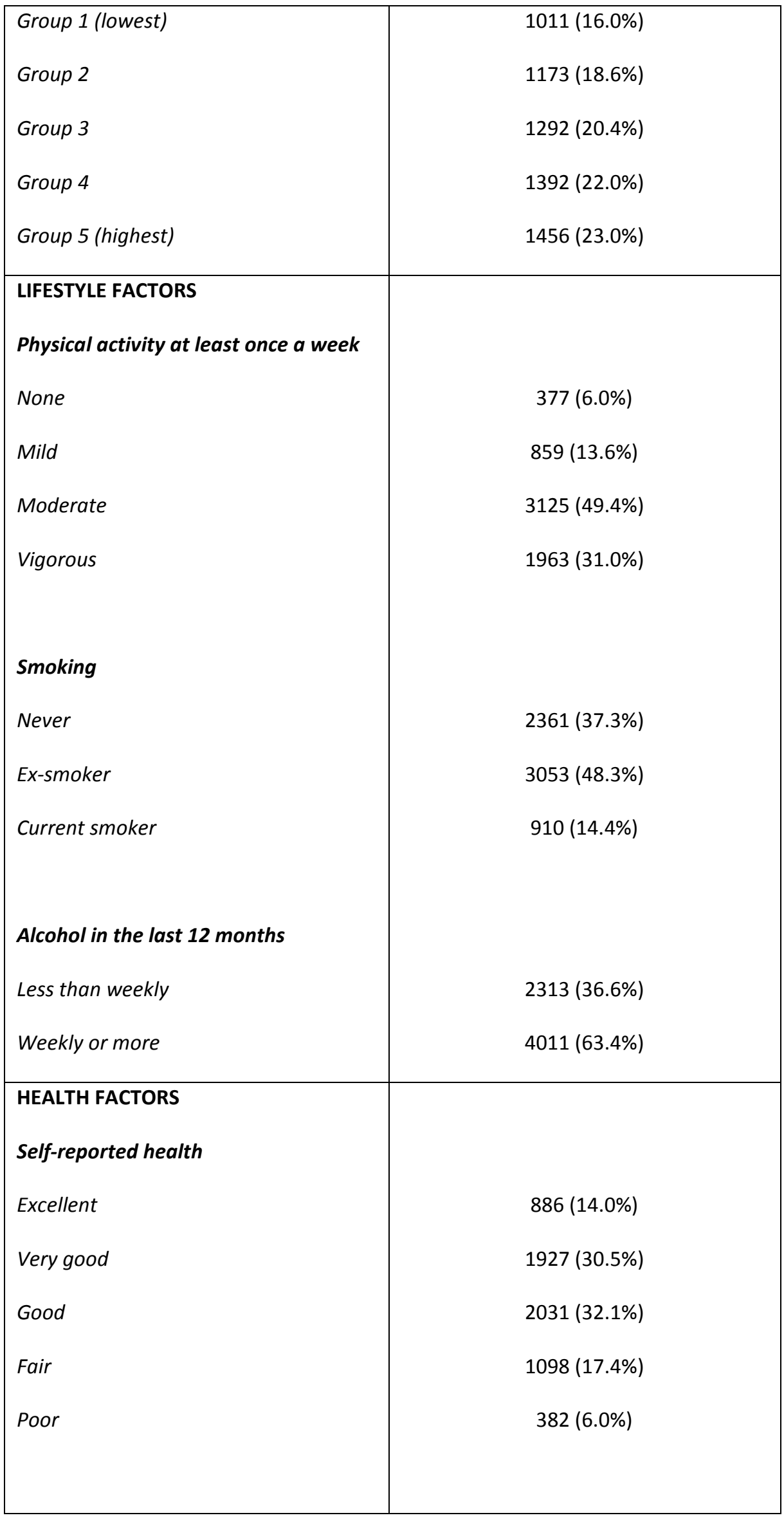




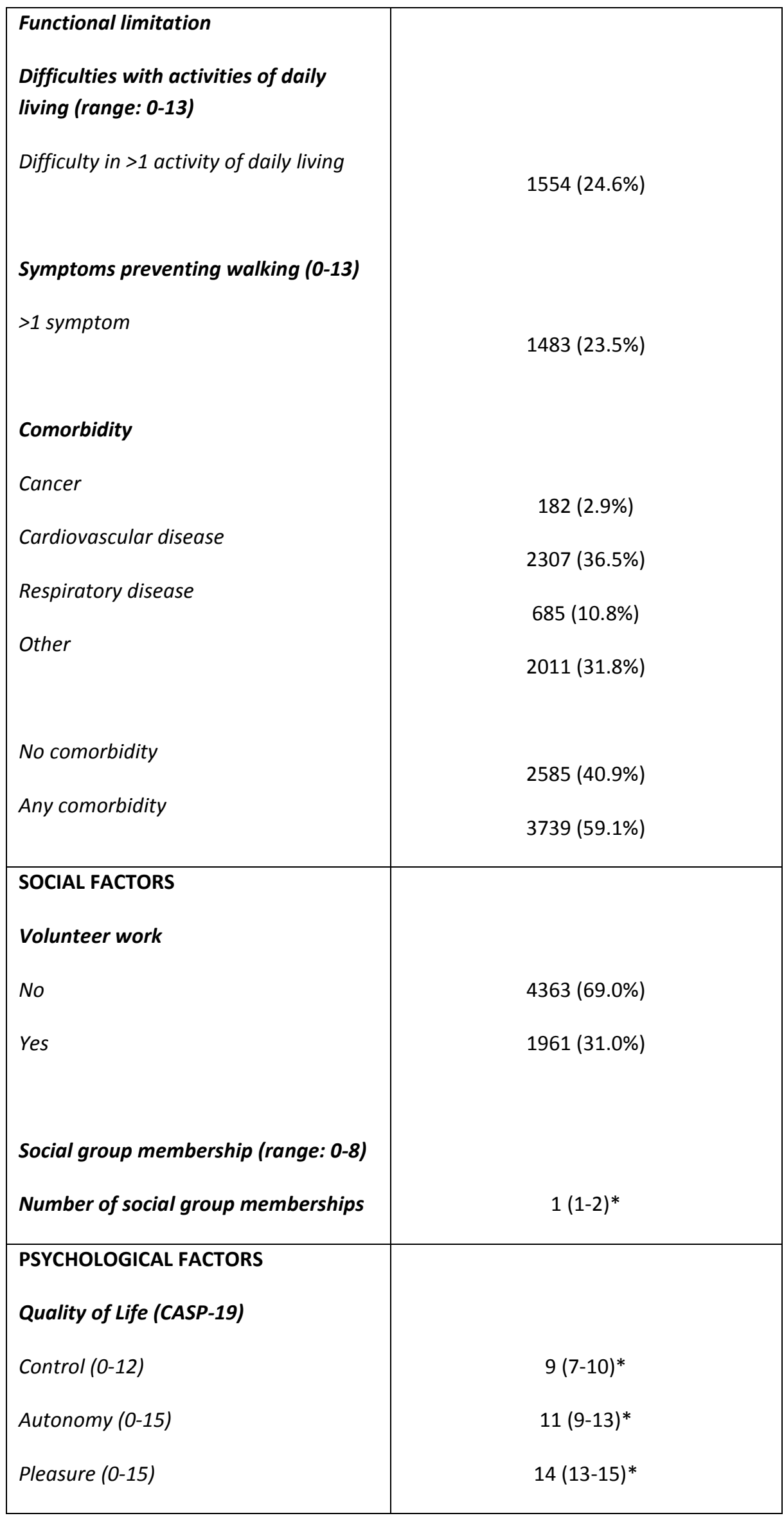




\begin{tabular}{|c|c|}
\hline Self-realisation (0-15) & $11(8-13)^{*}$ \\
\hline Total (0-57) & $44(38-50)^{*}$ \\
\hline Depression (CESD) (0-8) & $3(2-4)^{*}$ \\
\hline \multicolumn{2}{|l|}{ Depression (binary) } \\
\hline$<4$ depressive symptoms & $4619(73.0 \%)$ \\
\hline$=>4$ depressive symptoms & $1705(27.0 \%)$ \\
\hline \multicolumn{2}{|l|}{ Cognitive impairment } \\
\hline Number of words recalled (0-20) & $11(8-13)^{*}$ \\
\hline \multicolumn{2}{|c|}{ CASP $=$ Control, Autonomy, Self-realisation and Pleasure scale } \\
\hline \multicolumn{2}{|c|}{ CESD=Centre for Epidemiologic Studies Depression scale } \\
\hline \multicolumn{2}{|c|}{$N V Q=$ National Vocational Qualification } \\
\hline \multicolumn{2}{|c|}{ CSE $=$ Certificate of Secondary Education } \\
\hline \multicolumn{2}{|c|}{ GCE $=$ General Certificate of Education } \\
\hline Figures refer to $\mathrm{n}(\%), *$ indicates & e Range (IQR)) \\
\hline
\end{tabular}




\section{Lifestyle factors}

Pain is associated with and predicts an increase in harmful lifestyle factors which are linked with increased mortality. Examples of lifestyle factors (i.e. health related behaviours or the potential results of those behaviours (van Hecke, Torrance, \& Smith, 2013)) associated with pain are physical inactivity (McBeth \& Nicholl, 2010), smoking (Ditre \& Brandon, 2008) and alcohol consumption in men (Leveille et al., 2005).

\section{Physical inactivity}

The WHO defines physical activity as "any bodily movement produced by skeletal muscles that requires energy expenditure" (WHO website, 2015). Levels of physical activity are lower in people with pain often as a result of physical limitation (Kamaleri et al., 2008; McBeth \& Nicholl, 2010; Vogt, Lauerman, Chirumbole, \& Kuller, 2002). While there is concern that strenuous activity may cause some musculoskeletal problems, there is consistent evidence that regular moderate physical activity can reduce the persistence of pain and improve pain related function (Croft et al., 2010; Dugan et al., 2009).

Physical inactivity has been reported to be the fourth leading global risk factor for mortality, accounting for approximately 3.2 million deaths each year (WHO website, 2015). Frequent physical activity is protective against the development of chronic diseases such as cardiovascular disease, diabetes, cancer, hypertension, obesity, osteoporosis, depression and premature death (Warburton et al., 2006). Physical activity helps to improve bodily movement, reduce fatigue, control weight and enhance the immune system (Liu et al., 2011). Biological mechanisms responsible for the health benefits associated with physical activity include reduced abdominal adiposity and improved weight control, reduced triglyceride levels, increased high density lipoprotein (HDL) cholesterol levels and decreased low-density lipoprotein (LDL)-to-HDL ratios, improved glucose homeostasis and insulin sensitivity, reduced blood pressure, improved autonomic tone, reduced systemic inflammation; decreased blood coagulation, improved 
coronary blood flow, strengthened cardiac function and enhanced endothelial function (Warburton et al., 2006). The empirical analysis described in this study tested the hypothesis that pain would lead to increased mortality through physical inactivity.

\section{Smoking}

Cigarette smoking is one of the ten leading risk factors for death worldwide (Gellert, Schottker, \& Brenner, 2012). Compounds contained in cigarette smoke produce significant physiological effects, many of which are detrimental to health (Shi, Weingarten, Mantilla, Hooten, \& Warner, 2010). Smoking increases the risk of developing a large number of diseases including cancer of the lung, oesophagus, bladder, kidney and stomach, chronic obstructive pulmonary disease (COPD), coronary heart disease, stroke, peripheral vascular disease and peptic ulcer disease (Doll, Peto, Boreham, \& Sutherland, 2004; Fagerström, 2002) and is associated with the presence of chronically painful conditions such as fibromyalgia, rheumatoid arthritis and chronic musculoskeletal pain (Ditre \& Brandon, 2008; Zvolensky, McMillan, Gonzalez, \& Asmundson, 2010).

The pain-inhibiting effect of smoking through the analgesic properties of nicotine (Shi et al., 2010) supports the notion that some pain sufferers use smoking as a way of coping with their pain therefore pain is a motivator of smoking behaviour (Ditre \& Brandon, 2008). It was hypothesised that a link between pain and mortality would exist via smoking behaviour.

\section{Alcohol consumption}

Alcohol consumption may explain a relationship between pain and mortality. Excessive alcohol consumption is associated with the development of and death from liver cirrhosis (Rehm et al., 2010). Dreyer and colleagues (2010) reported increased mortality due to liver cirrhosis in fibromyalgia patients which suggests a pathway between pain and mortality via increased alcohol consumption (Dreyer et al., 2010). However, the relationship between pain and alcohol consumption is unclear. People experiencing pain may use alcohol as a way of coping with their 
pain; the use of alcohol for medicinal purposes is common in older people (Aira, Hartikainen, \& Sulkava, 2008). However, alcohol consumption is often lower in people with pain (Brennan, Schutte, SooHoo, \& Moos, 2011; McBeth \& Nicholl, 2010). This is partly consistent with the findings of Leveille et al., (2005) who observed that both men and women with widespread pain reported the lowest alcohol consumption, but men with single or multi-site pain were more likely to consume higher amounts of alcohol than men without pain (Leveille et al., 2005). Brennan and colleagues (2011) reported an association between more painful conditions and greater negative effects of alcohol consumption (e.g. physical or psychological problems or social conflicts) in men but not women indicating men and women respond differently to painful symptoms (Brennan et al., 2011). It was hypothesised pain would lead to mortality via increased alcohol consumption.

\section{Health factors}

Pain is associated with and predicts poor health (Blyth et al., 2015; Dominick, Blyth, \& Nicholas, 2012; Goldberg \& McGee, 2011). The World Health Organisation (WHO) defines health as "a state of complete physical, mental and social wellbeing and not merely the absence of disease and infirmity" (WHO, 1948). For the purposes of this study the secondary definition of health being "the extent to which an individual can realize aspirations, satisfy needs and change or cope with the environment" (WHO, 1984) is utilised to reflect functional ability. The association between pain and poor physical function increases with increasing pain severity (Landi et al., 2009, Ang, Kroenke, \& McHorney, 2006) and number of pain sites (Kamaleri et al., 2008), and the prevalence of pain that interferes with life increases with age (Thomas et al., 2007). Pain also leads to a reduction in perceptions of general heath (Reyes-Gibby, Aday, \& Cleeland, 2002) and this is an important determinant of health outcomes and mortality (Idler \& Benyamini, 1997).

Self-rated health 
Pain predicts poor self-rated health (Reyes-Gibby et al., 2002). Self-rated health is an individual's aggregated reflection of the many dimensions that affect health (Idler \& Benyamini, 1997; Jylhä, 2009). These include the evaluation of multiple illnesses and symptoms within an individual, judgements about illness severity, influences of family history and expectations of an individual's health trajectory, not just their current health (Idler \& Benyamini, 1997; Jylhä, 2009). Although this construct is based on perception and may be driven by mood, when measured using a single item (i.e. how good is your health? (Excellent, good, fair or poor)), poor self-rated health consistently predicted mortality and there was a dose response relationship between increased mortality and poorer rated health in a review of 27 studies using community samples (Idler \& Benyamini, 1997). Self-rated health may also reflect health behaviours, for example, poor perceptions of health may result in non-adherence to screening programmes or treatment (Idler \& Benyamini, 1997). It was hypothesised that pain would lead to poor selfrated health which in turn would lead to increased mortality through factors associated with poor ratings of health (e.g. illnesses, symptoms).

\section{Functional limitation}

The International Classification of Functioning, Disability and Health (ICF) identify three levels of human functioning; 1) body, 2) individual and 3) societal level. Disability is abnormal function at any of the three levels which are known as impairments, activity limitations or participation restriction respectively (World Health Organization, 2002). This section is focussed on limitation at the individual level (i.e. physical limitation which is when an individual has limited capacity to do simple physical tasks for example walk, go up and down stairs and pick up objects (World Health Organization, 2002)). Function within a social context is considered under the category of social factors.

Pain predicts functional limitation (Neogi, 2013). There is a dose-response relationship between increasing low back pain and increasing functional difficulty (Weiner, Haggerty, \& Kritchevsky, 
2003) and people reporting being often troubled with pain of moderate or severe intensity demonstrated higher rates of functional limitation than those without pain (Covinsky, Lindquist, Dunlop, \& Yelin, 2009). Pain (and conditions that pain is the main symptom of) accounts for 5 out of the 10 conditions responsible for the most years lived with disability (YLD) globally with low back pain accounting for $10.7 \%$ of all YLD (Buchbinder et al., 2013). Limitations in the ability to perform activities necessary for independent living and self-care are often used as indicators of disability (Chan, Kasper, Brandt, \& Pezzin, 2012). Increased functional impairment measured in this way was predictive of mortality in men and women over 65 over a 5 year period (Scott \& Macera, 1997) in adult Finnish population (aged 30-91 years, 72\% female) over a 5 year period (Sokka \& Pincus, 2011) and in an Italian population of adults aged over 80 years (Cesari et al., 2008). A systematic review of studies using objective measures of physical capability (e.g. walking speed, chair rises) reported low levels of such measures were consistent predictors of all-cause mortality in older community dwelling adults (Cooper, Kuh, Hardy, \& Mortality Review Group, 2010). It was therefore hypothesised pain would lead to mortality via functional limitation.

\section{Social factors}

Living with pain has a detrimental effect on relationships, interactions with others and on the families of the person with pain (Breivik et al., 2013; Henschke et al., 2015). Social participation involves interaction with other people in society or the community (Levasseur, Richard, Gauvin, \& Raymond, 2010). Participation restriction; difficulties with life situations such as working or shopping, is a negative social consequence of pain (Wilkie, Peat, Thomas, \& Croft, 2007). One in five people with chronic pain in Europe reported having lost their job because of pain and one third reported the amount of work they could do or whether they could work at all was affected by their pain (Breivik et al., 2006). 
Pain related interference is associated with a reduction in social networks (Peat, Thomas, Handy, \& Croft, 2004) and is also associated with neighbourhood deprivation and perceived income inadequacy (Jordan et al., 2008) which may reduce the ability and willingness to undertake social activities. Individuals with chronic pain report difficulty in attending social or family events and participating in recreational activities (Moulin et al., 2002).

\section{Social participation}

Participation restriction forms part of the ICF's definition of disability and refers to problems an individual has with involvement in life situations (World Health Organization, 2002). Most definitions of social participation focus on an individual's involvement in activities which involve interaction with others in society or the community (Levasseur et al., 2010). Social participation can help to protect against morbidity and mortality by promoting social interaction which positively influences the sympathetic nervous system and hormone levels such as cortisol which in turn affect blood pressure and the immune system (Holmes \& Joseph, 2011). Social participation and social functioning is reduced in people with chronic pain. In a study of chronic pain in Canada by Moulin et al., (2002), 49\% of individuals with chronic pain reported experiencing great difficulty in attending social or family events, $61 \%$ were unable to participate in their usual recreational activities and $58 \%$ could not carry out their usual activities at home (Moulin et al., 2002).

Volunteer work is a form of social participation which provides essential services focussed on creating a better community environment (Jenkinson et al., 2013). It is an important productive activity in older adults and has been shown to be a predictor of reduced mortality (Harris \& Thoresen, 2005; Musick, Herzog, \& House, 1999) and psychological well-being (Greenfield \& Marks, 2004). Pain and related functional limitations were predictors of restriction in paid or voluntary work in 50-59 year olds in North Staffordshire (Wilkie, Blagojevic-Bucknall, Jordan, \& Pransky, 2013). 
Social and productive activities like volunteering have been shown to confer equivalent survival advantages to fitness activities (Glass, de Leon, Marottoli, \& Berkman, 1999). The protective effect of volunteering is greatest in older adults with lower levels of informal social contact and in those who volunteer in moderate amounts but is less protective at higher levels where the detriments associated with role strain may offset any benefits (Musick et al., 1999). Proposed mechanisms linking volunteering to improved well-being include increased opportunity for social contacts and access to resources such as emotional, cognitive or material support and access to health related information (Luoh \& Herzog, 2002). It was hypothesised pain would lead to social participation restriction and this would in turn lead to an increased risk of mortality.

\section{Psychological factors}

People with persistent pain are more likely to have anxiety or depressive disorders than those without pain (Gureje \& Korff, 1998; Robinson et al., 2009). Suicidal ideation is three times more common in people with chronic pain compared to those without chronic pain (Tang \& Crane, 2006). The psychological processes of helplessness and hopelessness about pain, the desire for escape from pain, catastrophizing, avoidance and problem-solving deficits have been highlighted as important to understanding this suicidality (Tang \& Crane, 2006). Cognitive function is also reduced in individuals with pain (Moriarty, McGuire, \& Finn, 2011). Quality of life (QoL) and wellbeing are subjective perceptions which overlap with and interlink individual consequences of pain. They are closely related concepts and many definitions of each concept exist. The World Health Organisation define QoL as "an individual's perception of their position in life, in the context of the culture and value systems in which they live, and in relation to their goals, standards and concerns. QoL is a broad ranging concept, affected in a complex way by the person's physical health, psychological state, level of independence, social relationships and their relationship to salient features of their environment" (WHOQOL Group, 
1995). A more recent definition of wellbeing describes the concept as "an umbrella term for different valuations people make regarding their lives, the events happening to them, their bodies and minds and the circumstances in which they live" (Diener, 2006). Both of these definitions take into account life circumstances and values and reflect subjective rather than objective measures (Camfield \& Skevington, 2008). Ratings of QoL and wellbeing are influenced by the presence, combination and relative importance of different factors to the individual. As already outlined, reductions in a number of indicators of wellbeing are evident in individuals with pain and they do not act in isolation. For example, physical performance and disability levels are strongly associated with pain-related fear in patients with musculoskeletal pain syndromes like fibromyalgia. This can result in fear avoidance and depression, reducing daily function and quality of life for those people. These factors along with fatigue and sleep disturbance which are also consequences of pain may in turn result in a reduction of leisure time activity and social contact (Tüzün, 2007). Understanding such processes is important for our understanding of the impact of pain.

\section{Anxiety and Depression}

The World Health Organisation define depression as "a common mental disorder, characterised by sadness, loss of interest or pleasure, feelings of guilt or low self-worth, disturbed sleep or appetite, feelings of tiredness and poor concentration" (WHO, 2015c). Anxiety is a broad term used to describe a number of different disorders but general anxiety is often characterised by worrying thoughts, feelings of being tense and frightened, restlessness and panic (Mykletun et al., 2009). Symptoms of depression and anxiety often co-occur with chronic pain in primary care. Patients with a combination of pain and depression or pain and anxiety report greater severity of pain than those with pain alone, and those with both anxiety and depression report the most severe pain (Bair \& Wu, 2008). 
The prevalence of depression is greater in people with pain than in individuals without pain (Bair \& Robinson, 2003; Robinson et al., 2009). The relationship between pain and depression is reciprocal. Pain at baseline was an independent predictor of becoming depressed two years later, and depression at baseline predicted pain two years later in a study conducted using participants from the English Longitudinal Study of Aging (ELSA) (Chou, 2007).

The presence of pain can be a barrier to the recognition and treatment of depression (Bair \& Robinson, 2003) however, the conditions of pain and depression have been shown to share biological pathways and neurotransmitters and respond to similar treatment (Dunne, 2011). Activation of the HPA axis and the ascending and descending pain tracks are common to both conditions (Robinson et al., 2009).

Anxiety and depression are also associated with mortality (Mykletun et al., 2009). Increased mortality rates have been observed in both clinically and sub-clinically depressed individuals (Mykletun et al., 2009). Proposed mechanisms include suicide, increased hazardous health behaviours, higher rates of accidental deaths, and adverse effects of depression on endocrine, neurologic and endocrine processes, interference with a patient's motivation for recovery and by affecting compliance with treatment (Cuijpers \& Smit, 2002). Studies by Dreyer et al., (2010) and Wolfe et al., (2011) reported a significantly increased risk of death from suicide in patients with fibromyalgia (Dreyer et al., 2010) (Wolfe, Hassett, Walitt, \& Michaud, 2011). Many of the risk factors for suicide are also associated with chronic pain such as depression and histories of drug and alcohol abuse (Cheatle, 2011). Often opioids are prescribed for pain problems thus providing a potentially lethal medication to vulnerable people (Cheatle, 2011). An increase in the number of deaths due to poisoning with opioid analgesics has been observed in the United States between 1999 and 2006 (Warner, Chen, \& Makuc, 2009).

In a review of literature examining suicidality in chronic pain Tang and Crane (2006) found double the risk of suicide in patients with chronic pain relative to controls. They identified a 
number of risk factors associated with suicidality in chronic pain. These include type, intensity and duration of pain, insomnia, helplessness and hopelessness about pain, the desire for the escape from pain, pain catastrophising and avoidance and problem-solving deficits (Tang \& Crane, 2006).

Conversely, positive psychological wellbeing is associated with reduced mortality in both healthy populations and in those with existing physical illness (Chida \& Steptoe, 2008, Keyes \& Simoes, 2012). Depression was therefore hypothesised to be an intervening factor on a pathway between pain and mortality.

\section{Cognitive impairment}

Cognitive function refers to attention, learning and memory, speed of information processing, psychomotor and executive function (Moriarty et al., 2011). Cognitive impairment is common people with pain. It is an important determinant of independence in older adults and therefore an important component of healthy ageing (Llewellyn, Lang, Langa, \& Huppert, 2008). In a review of clinical and preclinical studies Moriarty et al., (2011) concluded that pain was associated with impaired attentional, executive and general cognitive functioning. They proposed the mechanisms were a result of pain competing with limited cognitive resources, neuroplasticity and dysregulated neurochemistry (Moriarty et al., 2011). Severe and mild cognitive impairment and poor memory performance is also associated with an increased risk of mortality (Bassuk, Wypij, \& Berkman, 2000; Shipley, Der, Taylor, \& Deary, 1985). Cognitive impairment has been shown to be associated with the presence of inflammatory markers and haemostasis (Rafnsson et al., 2007) or may be a side effect of analgesic medication (Moriarty et al., 2011) which may in turn lead to an increased risk of mortality. Cognitive decline is also associated with physical decline, an increased likelihood of being placed in a nursing home and subsequent increased mortality (Wolinsky et al., 2006). Cognitive impairment was therefore hypothesised to provide a link between pain and mortality. 


\begin{tabular}{|c|c|c|c|}
\hline Mediator & $\begin{array}{c}\text { Association between } \\
\text { often troubled with } \\
\text { pain and potential } \\
\text { mediator }\end{array}$ & Pathway & Adjusted HR (95\%Cl) \\
\hline & - & $\begin{array}{r}\begin{array}{r}\text { Total effect } \\
\text { (no }\end{array} \\
\text { mediators) }\end{array}$ & $1.30(1.12,1.50)$ \\
\hline $\begin{array}{l}\text { LIFESTYLE FACTORS } \\
\text { Physical activity } \\
\text { none/mild } \\
\text { moderate/vigorous }\end{array}$ & $\begin{array}{c}\text { Reference } \\
0.34(0.30,0.39)\end{array}$ & $\begin{array}{r}\text { Direct } \\
\text { Indirect } \\
\text { Total }\end{array}$ & $\begin{array}{l}1.14(0.98,1.33) \\
1.14(1.10,1.20) \\
1.30(1.14,1.51)\end{array}$ \\
\hline $\begin{array}{l}\text { Smoking } \\
\text { Non-smoker (Reference) } \\
\text { Current smoker }\end{array}$ & $\begin{array}{c}\text { Reference } \\
1.07(0.92,1.25)\end{array}$ & $\begin{array}{r}\text { Direct } \\
\text { Indirect } \\
\text { Total }\end{array}$ & $\begin{array}{l}1.29(1.12,1.50) \\
1.01(0.99,1.02) \\
1.30(1.14,1.51)\end{array}$ \\
\hline $\begin{array}{l}\text { Alcohol consumption } \\
<\text { weekly (low) } \\
>\text { weekly (high) }\end{array}$ & $\begin{array}{c}\text { Reference } \\
0.71(0.64,0.80)\end{array}$ & $\begin{array}{r}\text { Direct } \\
\text { Indirect } \\
\text { Total }\end{array}$ & $\begin{array}{l}1.28(1.12,1.49) \\
1.01(1.00,1.02) \\
1.30(1.14,1.51)\end{array}$ \\
\hline $\begin{array}{l}\text { HEALTH } \\
\text { Self-reported health } \\
\text { Poor/Fair } \\
\text { Good/Very good/Excellent }\end{array}$ & $\begin{array}{c}\text { Reference } \\
0.18(0.16,0.21)\end{array}$ & $\begin{array}{r}\text { Direct } \\
\text { Indirect } \\
\text { Total }\end{array}$ & $\begin{array}{l}0.99(0.84,1.16) \\
1.32(1.23,1.41) \\
1.30(1.14,1.52)\end{array}$ \\
\hline $\begin{array}{l}\text { Functional limitation } \\
\text { (ADL/IADL difficulties) } \\
\text { No difficulties } \\
\text { Any difficulties }\end{array}$ & $\begin{array}{c}\text { Reference } \\
6.40(5.61,7.31)\end{array}$ & $\begin{array}{r}\text { Direct } \\
\text { Indirect } \\
\text { Total }\end{array}$ & $\begin{array}{l}1.00(0.86,1.16) \\
1.31(1.20,1.39) \\
1.31(1.14,1.51)\end{array}$ \\
\hline $\begin{array}{l}\text { Symptoms preventing walking } 1 / 4 \\
\text { mile } \\
\text { No symptoms } \\
\text { Any symptoms }\end{array}$ & $\begin{array}{c}\text { Reference } \\
8.17(7.08,9.45)\end{array}$ & $\begin{array}{l}\text { Direct } \\
\text { Indirect }\end{array}$ & $\begin{array}{l}0.89(0.78,1.04) \\
1.45(1.35,1.58)\end{array}$ \\
\hline
\end{tabular}




\begin{tabular}{|c|c|c|c|}
\hline & & Total & $1.30(1.13,1.51)$ \\
\hline $\begin{array}{l}\text { SOCIAL FACTORS } \\
\text { Social group membership } \\
0-1 \text { group } \\
2 \text { or more groups }\end{array}$ & $\begin{array}{c}\text { Reference } \\
0.86(0.77,0.96)\end{array}$ & $\begin{array}{r}\text { Direct } \\
\text { Indirect } \\
\text { Total }\end{array}$ & $\begin{array}{l}1.29(1.12,1.50) \\
1.01(1.00,1.02) \\
1.30(1.14,1.51)\end{array}$ \\
\hline $\begin{array}{l}\text { Volunteer work } \\
\text { None } \\
\text { Any }\end{array}$ & $\begin{array}{c}\text { Reference } \\
0.85(0.76,0.96)\end{array}$ & $\begin{array}{r}\text { Direct } \\
\text { Indirect } \\
\text { Total }\end{array}$ & $\begin{array}{l}1.29(1.12,1.50) \\
1.01(1.00,1.02) \\
1.30(1.14,1.51)\end{array}$ \\
\hline $\begin{array}{l}\text { PSYCHOLOGICAL FACTORS } \\
\text { Quality of life } \\
\text { < median (low) } \\
\text { >median (high) }\end{array}$ & $\begin{array}{c}\text { Reference } \\
0.37(0.33,0.41)\end{array}$ & $\begin{array}{r}\text { Direct } \\
\text { Indirect } \\
\text { Total }\end{array}$ & $\begin{array}{l}1.18(1.02,1.36) \\
1.10(1.07,1.14) \\
1.30(1.13,1.51)\end{array}$ \\
\hline $\begin{array}{l}\text { Control } \\
<\text { median (low) } \\
>\text { median (high) }\end{array}$ & $\begin{array}{c}\text { Reference } \\
\mathbf{0 . 4 6}(\mathbf{0 . 4 1 , 0 . 5 2 )}\end{array}$ & $\begin{array}{r}\text { Direct } \\
\text { Indirect } \\
\text { Total }\end{array}$ & $\begin{array}{l}1.23(1.07,1.44) \\
1.06(1.03,1.08) \\
1.30(1.14,1.51)\end{array}$ \\
\hline $\begin{array}{l}\text { Autonomy } \\
<\text { median(low) } \\
>\text { median(high) }\end{array}$ & $\begin{array}{c}\text { Reference } \\
0.38(0.34,0.42)\end{array}$ & $\begin{array}{r}\text { Direct } \\
\text { Indirect } \\
\text { Total }\end{array}$ & $\begin{array}{l}1.22(1.06,1.41) \\
1.07(1.03,1.10) \\
1.30(1.14,1.51)\end{array}$ \\
\hline $\begin{array}{l}\text { Pleasure } \\
<\text { median (low) } \\
\text { >median (high) }\end{array}$ & $\begin{array}{c}\text { Reference } \\
0.63(0.56,0.70)\end{array}$ & $\begin{array}{r}\text { Direct } \\
\text { Indirect } \\
\text { Total }\end{array}$ & $\begin{array}{l}1.27(1.11,1.49) \\
1.02(1.00,1.04) \\
1.30(1.14,1.51)\end{array}$ \\
\hline $\begin{array}{l}\text { Self-realisation } \\
<\text { median (low) } \\
>\text { median (high) }\end{array}$ & $\begin{array}{c}\text { Reference } \\
\mathbf{0 . 4 8}(\mathbf{0 . 4 3 , 0 . 5 4 )}\end{array}$ & $\begin{array}{r}\text { Direct } \\
\text { Indirect } \\
\text { Total }\end{array}$ & $\begin{array}{l}1.24(1.06,1.41) \\
1.05(1.03,1.08)\end{array}$ \\
\hline
\end{tabular}




\begin{tabular}{|c|c|c|c|}
\hline Depression & & Direct & $1.20(1.04,1.38)$ \\
\hline Not depressed (CESD score) $<4$ & Reference & Indirect & $1.09(1.05,1.12)$ \\
\hline Depressed $>4$ & $2.62(2.33,2.95)$ & Total & $1.30(1.13,1.51)$ \\
\hline Cognitive impairment & & Direct & $1.29(1.12,1.49)$ \\
\hline$<$ median (low ability) & Reference & Indirect & $1.01(1.00,1.02)$ \\
\hline > median (high ability) & $0.83(0.74,0.93)$ & Total & $1.30(1.13,1.51)$ \\
\hline \multicolumn{4}{|c|}{ All models adjusted for age, sex, education and wealth } \\
\hline \multicolumn{4}{|l|}{ OR = Odds ratio } \\
\hline \multicolumn{4}{|l|}{$\mathrm{HR}=$ Hazard ratio } \\
\hline \multicolumn{4}{|l|}{$\mathrm{Cl}=$ Confidence Intervals } \\
\hline \multicolumn{4}{|c|}{ Significant associations between predictor and mediator and indirect effects are in bold } \\
\hline
\end{tabular}




\section{Lifestyle factors}

Physical activity

Participants were asked to indicate whether they took part in vigorous, moderate or mild physical activities more than once a week, once a week, one to three times a month or hardly ever. Similar to previous research, [3] four physical activity categories were derived (none, mild activity, moderate and vigorous activity at least once a week). Three dichotomous variables were created for vigorous, moderate and mild activities scored as 1 if a participant indicated they took part in that level of activity once a week or more and 0 if not. A summary variable was then created whereby if participants scored 1 for vigorous activity more than once a week they were allocated to this category, if they indicated moderate activity and did not separately indicate vigorous activity they were allocated to the 'moderate' category. It they indicated mild activity at least once a week and did not also indicate moderate or vigorous activity they were allocated to the 'mild' activity category. If they did not indicate activity at any of the above levels at least once a week they were allocated to the 'no activity' category. This variable was then dichotomised for use in the mediation analysis to compare no/mild activity to moderate/vigorous activity at least once a week. No/mild activity has previously been used to form a category of low activity in ELSA [3] and this formed the reference group for the analysis.

\section{Smoking}

Smoking status was determined by asking participants to indicate whether they never smoked, used to be an occasional, regular or frequent smoker, or were a current smoker. The dichotomous variable used in the mediation analysis compared non-smokers (never and past) (reference) to current smokers. 


\section{Alcohol consumption}

Participants were asked about the frequency of their alcohol consumption over the last 12 months. Responses options were 'not at all', 'once or twice a year', 'once every couple of months', 'once or twice a month', 'once or twice a week', three or four times a week', 'five or six days a week', and 'almost every day'. These options were categorised to alcohol consumption less than weekly (reference) and weekly or more often.

\section{Health factors}

\section{Self-rated health}

Participants were asked to indicate how they rated their health; 'excellent', 'very good', 'good', 'fair' or 'poor'. This variable was dichotomised to compare poor/fair ratings as the reference group to good, very good and excellent.

\section{Functional limitation}

Functional limitation was assessed using measurements of activities of daily living (ADL) (dressing, walking across a room, bathing or showering, eating, getting in or out of bed and using the toilet) and instrumental ADLs (IADLs) (map reading, preparing a hot meal, shopping for groceries, making telephone calls, taking medications, doing work around the house and garden and managing money). Participants scored 1 if they indicated difficulties with any of these activities and items were summed to form a scale ranging from 0-13. Functional limitations were dichotomised around the median score (0) to produce categories of high and low limitation. This resulted in a comparison between no difficulties (reference) and any difficulties ( $24.57 \%$ of the study sample).

Symptoms preventing walking 
Participants were asked to specify what symptoms made it difficult for them to walk quarter of a mile. Options were chest pain, fatigue/too tired, shortness of breath, tremor, pain in leg or foot, swelling in leg or foot, incontinence, seeing difficulty, hearing difficulty, confusion, difficulty concentrating, memory problems, unsteady on feet or balance problems, lightheaded or dizziness, fear of falling, anxiety or fear or other problem or symptom. Variables were recoded and a single symptom count variable was created. This was again dichotomised around the median score to produce a category of high symptom count compared to a category of low symptom count. Using the median again resulted in a comparison between no difficulties (reference) and any difficulties.

\section{Social factors}

\section{Social group membership}

Group membership has been used as a measure of social participation in older adults in ELSA and was found to be an independent predictor of cardiovascular risk factors [5]. Group membership was measured using eight items. Each participant reported current membership of or participation in (1) political party, trade union or environmental groups, (2) tenants groups, resident groups or neighbourhood watch, (3) church or other religious groups, (4) charitable associations, (5) education, art or music groups or evening classes, (6) social club, (7) sports club, gym or exercise classes or (8) any other organisations club or societies [5]. The total score (0-8) was dichotomised at the median with membership of 0 or 1 group (reference) being compared to membership of 2 or more groups allowing low and high social group membership to be compared.

\section{Volunteer work}


Participants were asked to indicate whether they undertook any voluntary work. This was dichotomised into 'yes' if they indicated any frequency of volunteer work and 'no' if they indicated they never did [1]. This dichotomy of volunteer work has been used previously in ELSA and undertaking volunteer work was shown to be associated with increased quality of life in older adults [8], reduced depression and greater life satisfaction [7].

\section{Psychological factors}

\section{Quality of life}

In ELSA, quality of life was measured using the CASP-19 (Control, Autonomy, Self-realisation and Pleasure) scale which was designed in a population of adults in early old age (65-75 years) [4]. CASP-19 has 19 items which map to four domains; control (4 items) for example 'I feel free to plan for the future', autonomy (5 items) for example 'I feel that I can please myself what I do', self-realisation ( 5 items) for example 'I feel that life is full of opportunities' and pleasure for example 'I enjoy the things that I do' (5 items). Responses options are 'often', 'sometimes', 'not often' and 'never' and are scored 3-0 unless negatively worded where this is reversed. The psychometric properties (factor structure, content validity) of CASP-19 support its application in population studies and a test comparing the total model, a domain only model and a total and domain model demonstrated little difference between the latter two models indicating it is better to present the individual domain scores alongside the total quality of life score to give the scale greater utility [10]. The enjoyment of life domain has previously been shown to be associated with longer survival in the ELSA dataset [12]. All quality of life domains were dichotomised at the median score for use in the mediation analysis to represent high (above the median) and low (below the median) quality of life specific to each domain (median scores were: Control 
= $9($ IQR 7-10), autonomy = 11 (IQR 9-13), self-realisation = $11($ IQR 8-13), pleasure = 14 (IQR

13-15), total = $44($ IQR 38-50)).

\section{Anxiety and depression}

In ELSA depression was measured using the eight item version of the 20 item Centre for Epidemiological Studies Depression (CES-D) scale. The CES-D is a short, structured selfreport measure developed to assess depressive symptoms in epidemiological studies [9]. The reliability and factor structure of the 8 item scale has been tested and deemed to have internal consistency and be unidimensional $[2,11]$. Participants respond yes or no to eight questions regarding depressive symptoms (Table AVII.2). Responses were summed to give a score between 0 and 8 (two items worded in the positive direction were reverse scored) (Banks et al., 2014). The score was then dichotomised to no depression (score of 0 to 3 ) (reference) and possible case (score of 4 or more) [11].

\begin{tabular}{|l|}
\hline $\begin{array}{l}\text { Table AVII.2 Items of the } 8 \text { item version of the CES-D } \\
\text { (reproduced from Van de Velde, Levecque, } \boldsymbol{\&} \\
\text { Bracke, 2009) }\end{array}$ \\
\hline Much of the time during the past week... \\
\hline ...did you feel depressed? \\
\hline ...did you feel everything you did was an effort? \\
\hline ...was your sleep restless? \\
\hline ...were you happy? \\
\hline ...did you feel lonely? \\
\hline ...did you enjoy life? \\
\hline ...did you feel sad? \\
\hline ...were you unable to get going? \\
\hline
\end{tabular}




\section{Cognitive impairment}

Cognitive impairment was measured using a memory test consisting of 10 words respondents were asked to recall immediately and five minutes later. The words were common nouns and were presented aurally by a computer. One word was presented every two seconds. Four different word lists were used interchangeably to ensure different versions of the test were administered to members of the same household [6]. The total number of words recalled (range 0-20) was used as an indication of memory [1]. This was dichotomised around the median comparing a score of 0-10 (low cognitive ability) (reference) with 11-20 (high cognitive ability).

\section{References}

[1] Banks J, Batty D, Bridges S, Oliveira C De, Hussey D, Matthews K. Wave 6 The Dynamics of Ageing October 2014. 2012 p.

[2] Gallo W, Bradley E. The persistence of depressive symptoms in older workers who experience involuntary job loss: results from the health and retirement survey. Journals ... 2006;61:S221-228. Available: http://psychsocgerontology.oxfordjournals.org/content/61/4/S221.short. Accessed 21 Oct 2013.

[3] Hamer M, Molloy GJ, de Oliveira C, Demakakos P. Leisure time physical activity, risk of depressive symptoms, and inflammatory mediators: the English Longitudinal Study of Ageing. Psychoneuroendocrinology 2009;34:1050-5.

doi:10.1016/j.psyneuen.2009.02.004. 
[4] Hyde M, Wiggins RD, Higgs P, Blane DB. A measure of quality of life in early old age: the theory, development and properties of a needs satisfaction model (CASP-19). Aging Ment. Health 2003;7:186-94. doi:10.1080/1360786031000101157.

[5] Kamiya $\mathrm{Y}$, Whelan B, Timonen V, Kenny RA. The differential impact of subjective and objective aspects of social engagement on cardiovascular risk factors. BMC Geriatr. 2010;10:81. doi:10.1186/1471-2318-10-81.

[6] Llewellyn DJ, Lang I a, Langa KM, Huppert F a. Cognitive function and psychological well-being: findings from a population-based cohort. Age Ageing 2008;37:685-9. doi:10.1093/ageing/afn194.

[7] McMUNN A, Nazroo J, Wahrendorf M, Breeze E, Zaninotto P. Participation in sociallyproductive activities, reciprocity and wellbeing in later life: baseline results in England. Ageing Soc. 2009;29:765. doi:10.1017/S0144686X08008350.

[8] Netuveli G, Wiggins RD, Hildon Z, Montgomery SM, Blane D. Quality of life at older ages: evidence from the English longitudinal study of aging (wave 1). J. Epidemiol. Community Health 2006;60:357-63. doi:10.1136/jech.2005.040071.

[9] Radloff L. The CES-D scale a self-report depression scale for research in the general population. Appl. Psychol. Meas. 1977:385-401. Available: http://apm.sagepub.com/content/1/3/385.short. Accessed 21 Oct 2013.

[10] Sim J, Bartlam B, Bernard M. The CASP-19 as a measure of quality of life in old age: evaluation of its use in a retirement community. Qual. Life Res. 2011;20:997-1004. doi:10.1007/s11136-010-9835-x. 
[11] Steffick DE. Documentation of affective functioning measures in the Health and Retirement Study. HRS/AHEAD Doc. Rep. 2000.

[12] Steptoe A, Wardle J. Enjoying life and living longer. Arch. Intern. Med. 2012;172:273275. doi:10.1016/j.celrep.2011.1011.1001.7.

[13] Van de Velde S, Levecque K, Bracke P. Measurement equivalence of the CES-D 8 in the general population in Belgium: a gender perspective. Arch. Public Heal. 2009;67:15. doi:10.1186/0778-7367-67-1-15. 


\begin{tabular}{|c|c|c|c|c|c|c|}
\hline & \multicolumn{3}{|c|}{$\begin{array}{l}\text { Moderate to severe pain compared with mild/not often troubled } \\
\text { Total Effect (no mediators): } \\
1.44(1.24,1.67)\end{array}$} & \multicolumn{3}{|c|}{$\begin{array}{l}\text { Severe pain compared with moderate/mild/not often troubled } \\
\text { Total Effect (no mediators): } \\
1.35(1.06,1.72)\end{array}$} \\
\hline Mediator & $\begin{array}{l}\text { Association between pain and } \\
\text { mediator } \\
\text { Adjusted OR }(95 \% \mathrm{Cl})\end{array}$ & Pathway & $\frac{\text { Adjusted HR }}{\underline{(95 \% \mathrm{Cl})}}$ & $\begin{array}{l}\text { Association between pain and } \\
\text { mediator } \\
\text { Adjusted OR }(95 \% \mathrm{Cl})\end{array}$ & Pathway & $\begin{array}{l}\text { Adjusted HR } \\
\underline{(95 \% \mathrm{Cl})} \\
\end{array}$ \\
\hline Physical Activity & $0.33(0.29,0.38)$ & $\begin{array}{l}\text { Direct } \\
\text { Indirect } \\
\text { Total }\end{array}$ & $\begin{array}{l}1.23(1.05,1.45) \\
1.17(1.12,1.22) \\
1.44(1.22,1.69)\end{array}$ & $0.34(0.27,0.42)$ & $\begin{array}{l}\text { Direct } \\
\text { Indirect } \\
\text { Total }\end{array}$ & $\begin{array}{l}1.10(0.82,1.42) \\
1.18(1.12,1.24) \\
1.29(0.97,1.66) \\
\end{array}$ \\
\hline Smoking & $1.22(1.03,1.43)$ & $\begin{array}{l}\text { Direct } \\
\text { Indirect } \\
\text { Total }\end{array}$ & $\begin{array}{l}1.42(1.22,1.66) \\
1.01(1.00,1.03) \\
1.44(1.24,1.69)\end{array}$ & $1.26(0.96,1.63)$ & $\begin{array}{l}\text { Direct } \\
\text { Indirect } \\
\text { Total }\end{array}$ & $\begin{array}{l}1.33(1.02,1.68) \\
1.02(1.00,1.04) \\
1.35(1.03,1.71)\end{array}$ \\
\hline Alcohol Consumption & $1.33(1.17,1.52)$ & $\begin{array}{l}\text { Direct } \\
\text { Indirect } \\
\text { Total } \\
\end{array}$ & $\begin{array}{l}1.44(1.23,1.67) \\
1.00(0.99,1.01) \\
1.44(1.23,1.67) \\
\end{array}$ & $1.52(1.19,1.96)$ & $\begin{array}{l}\text { Direct } \\
\text { Indirect } \\
\text { Total } \\
\end{array}$ & $\begin{array}{l}1.36(1.06,1.72) \\
1.00(0.99,1.02) \\
1.36(1.06,1.72) \\
\end{array}$ \\
\hline Self-reported health & $5.46(4.71,6.36)$ & $\begin{array}{l}\text { Direct } \\
\text { Indirect } \\
\text { Total }\end{array}$ & $\begin{array}{l}1.18(1.00,1.38) \\
1.22(1.17,1.29) \\
1.44(1.24,1.66)\end{array}$ & $6.60(4.78,9.35)$ & $\begin{array}{l}\text { Direct } \\
\text { Indirect } \\
\text { Total }\end{array}$ & $\begin{array}{l}1.09(0.83,1.41) \\
1.22(1.16,1.27) \\
1.32(1.01,1.70)\end{array}$ \\
\hline Functional limitation & $6.87(6.01,7.86)$ & $\begin{array}{l}\text { Direct } \\
\text { Indirect } \\
\text { Total } \\
\end{array}$ & $\begin{array}{l}1.10(0.93,1.31) \\
1.32(1.22,1.42) \\
1.45(1.24,1.70)\end{array}$ & $8.16(6.47,10.34)$ & $\begin{array}{l}\text { Direct } \\
\text { Indirect } \\
\text { Total } \\
\end{array}$ & $\begin{array}{l}1.00(0.72,1.34) \\
1.36(1.26,1.47) \\
1.36(1.00,1.77) \\
\end{array}$ \\
\hline $\begin{array}{l}\text { Symptoms preventing walking } \\
1 / 4 \text { mile }\end{array}$ & $9.22(7.99,10.66)$ & $\begin{array}{l}\text { Direct } \\
\text { Indirect } \\
\text { Total }\end{array}$ & $\begin{array}{l}0.96(0.81,1.16) \\
1.50(1.38,1.63) \\
1.44(1.22,1.71)\end{array}$ & $10.32(8.10,13.23)$ & $\begin{array}{l}\text { Direct } \\
\text { Indirect } \\
\text { Total }\end{array}$ & $\begin{array}{l}0.91(0.68,1.20) \\
1.49(1.37,1.60) \\
1.36(1.02,1.77)\end{array}$ \\
\hline
\end{tabular}




\begin{tabular}{|c|c|c|c|c|c|c|}
\hline Social group membership & 1 & $\begin{array}{l}\text { Direct } \\
\text { Indirect } \\
\text { Total }\end{array}$ & $\begin{array}{l}1.44(1.24,1.67) \\
1.00(1,1) \\
1.44(1.24,1.67)\end{array}$ & 1 & $\begin{array}{l}\text { Direct } \\
\text { Indirect } \\
\text { Total }\end{array}$ & $\begin{array}{l}1.35(1.06,1.72) \\
1.00(1,1) \\
1.35(1.06,1.72)\end{array}$ \\
\hline Volunteer work & $0.79(0.69,0.90)$ & $\begin{array}{l}\text { Direct } \\
\text { Indirect } \\
\text { Total }\end{array}$ & $\begin{array}{l}1.42(1.22,1.64) \\
1.01(1.00,1.03) \\
1.44(1.24,1.67)\end{array}$ & $0.73(0.56,0.94)$ & $\begin{array}{l}\text { Direct } \\
\text { Indirect } \\
\text { Total }\end{array}$ & $\begin{array}{l}1.32(1.02,1.68) \\
1.02(1.00,1.04) \\
1.35(1.04,1.72)\end{array}$ \\
\hline Quality of life & $0.32(0.28,0.37)$ & $\begin{array}{l}\text { Direct } \\
\text { Indirect } \\
\text { Total }\end{array}$ & $\begin{array}{l}1.30(1.09,1.52) \\
1.11(1.07,1.16) \\
1.44(1.23,1.68)\end{array}$ & $0.30(0.23,0.38)$ & $\begin{array}{l}\text { Direct } \\
\text { Indirect } \\
\text { Total }\end{array}$ & $\begin{array}{l}1.20(0.92,1.57) \\
1.12(1.08,1.16) \\
1.35(1.03,1.74)\end{array}$ \\
\hline Control & $0.38(0.34,0.43)$ & $\begin{array}{l}\text { Direct } \\
\text { Indirect } \\
\text { Total }\end{array}$ & $\begin{array}{l}1.29(1.09,1.52) \\
1.11(1.07,1.15) \\
1.44(1.22,1.69)\end{array}$ & $0.40(0.32,0.50)$ & $\begin{array}{l}\text { Direct } \\
\text { Indirect } \\
\text { Total }\end{array}$ & $\begin{array}{l}1.26(0.98,1.59) \\
1.11(1.07,1.15) \\
1.40(1.09,1.77) \\
\end{array}$ \\
\hline Autonomy & $0.34(0.30,0.38)$ & $\begin{array}{l}\text { Direct } \\
\text { Indirect } \\
\text { Total }\end{array}$ & $\begin{array}{l}1.35(1.17,1.59) \\
1.07(1.02,1.11) \\
1.44(1.24,1.69)\end{array}$ & $0.30(0.24,0.37)$ & $\begin{array}{l}\text { Direct } \\
\text { Indirect } \\
\text { Total }\end{array}$ & $\begin{array}{l}1.30(0.99,1.67) \\
1.08(1.04,1.13) \\
1.41(1.09,1.78)\end{array}$ \\
\hline Pleasure & $0.57(0.51,0.64)$ & $\begin{array}{l}\text { Direct } \\
\text { Indirect } \\
\text { Total } \\
\end{array}$ & $\begin{array}{l}1.40(1.20,1.64) \\
1.03(1.01,1.05) \\
1.44(1.23,1.68)\end{array}$ & $0.62(0.50,0.76)$ & $\begin{array}{l}\text { Direct } \\
\text { Indirect } \\
\text { Total }\end{array}$ & $\begin{array}{l}1.30(1.00,1.64) \\
1.03(1.01,1.05) \\
1.33(1.03,1.67) \\
\end{array}$ \\
\hline Self-realisation & $0.43(0.38,0.48)$ & $\begin{array}{l}\text { Direct } \\
\text { Indirect } \\
\text { Total }\end{array}$ & $\begin{array}{l}1.33(1.13,1.56) \\
1.08(1.05,1.11) \\
1.44(1.23,1.67)\end{array}$ & $0.49(0.39,0.61)$ & $\begin{array}{l}\text { Direct } \\
\text { Indirect } \\
\text { Total }\end{array}$ & $\begin{array}{l}1.25(0.96,1.60) \\
1.07(1.04,1.10) \\
1.34(1.03,1.72)\end{array}$ \\
\hline Depression & $3.01(2.66,3.41)$ & $\begin{array}{l}\text { Direct } \\
\text { Indirect } \\
\text { Total }\end{array}$ & $\begin{array}{l}1.31(1.13,1.51) \\
1.11(1.07,1.16) \\
1.45(1.26,1.66)\end{array}$ & $3.29(2.66,4.07)$ & $\begin{array}{l}\text { Direct } \\
\text { Indirect } \\
\text { Total }\end{array}$ & $\begin{array}{l}1.21(0.94,1.54) \\
1.14(1.09,1.20) \\
1.38(1.06,1.76)\end{array}$ \\
\hline Cognitive impairment & $0.78(0.69,0.89)$ & $\begin{array}{l}\text { Direct } \\
\text { Indirect } \\
\text { Total }\end{array}$ & $\begin{array}{l}1.41(1.21,1.64) \\
1.01(1.00,1.03) \\
1.44(1.23,1.67)\end{array}$ & $0.71(0.57,0.89)$ & $\begin{array}{l}\text { Direct } \\
\text { Indirect } \\
\text { Total }\end{array}$ & $\begin{array}{l}1.34(1.04,1.71) \\
1.02(1.01,1.04) \\
1.37(1.05,1.75)\end{array}$ \\
\hline \multicolumn{7}{|c|}{$\begin{array}{l}\text { All models adjusted for age, sex, education and wealth } \\
\mathrm{OR}=\text { Odds ratio } \\
\mathrm{HR}=\text { Hazard ratio } \\
\mathrm{Cl}=\text { Confidence Intervals } \\
\text { Significant associations between predictor and mediator and indirect effects are in bold }\end{array}$} \\
\hline
\end{tabular}


$\mathrm{R}$ code for mediation analysis within survival analysis

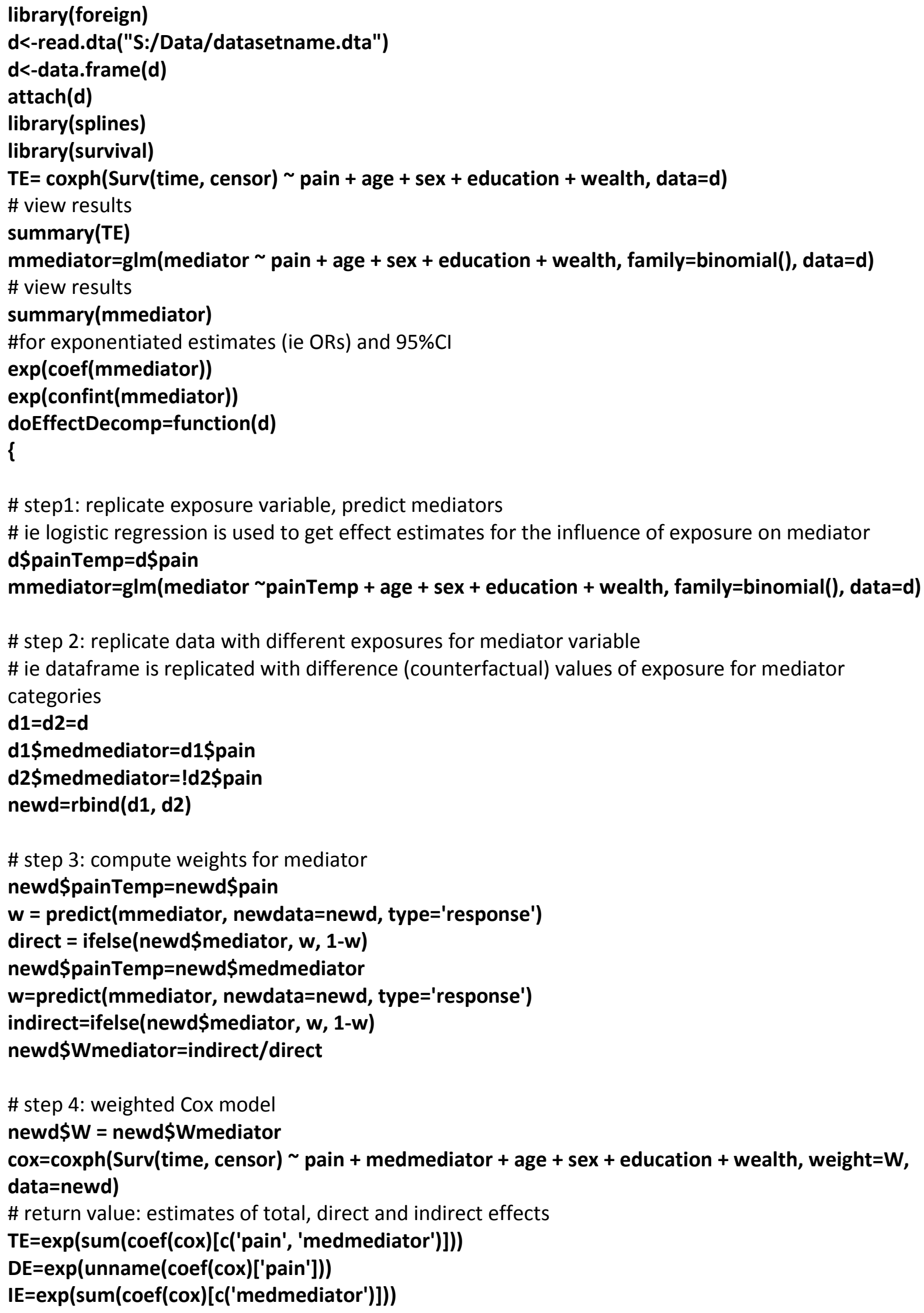


Step 5: get 95\% confidence intervals for estimates obtained in step 4: step 4 doesn't produce confidence intervals so need to do bootstrap resampling

csamp=function(d)

\{

$s=s a m p l e($ unique(d\$surveyid), replace=TRUE)

return(do.call('rbind', lapply(s, function(x) d[d\$surveyid $==x])$,$) )$

\}

HRs = replicate(100, doEffectDecomp(csamp(d)))

apply(HRs, 1, quantile, c(0.025, 0.975)) 


\begin{tabular}{|c|c|c|c|c|}
\hline \multicolumn{5}{|c|}{ Supplementary Table 1 Measures of the proposed mediating factors in the ELSA dataset } \\
\hline Domain & Variable & Operationalised & Categories from raw data & Categories for analysis \\
\hline \multirow[t]{3}{*}{$\begin{array}{l}\text { Lifestyle } \\
\text { factors }\end{array}$} & Physical activity & $\begin{array}{l}3 \text { items: (How often take part } \\
\text { in...) } \\
\text { mild, moderate or vigorous } \\
\text { activity }\end{array}$ & $\begin{array}{l}\text { More than once a week } \\
\text { Once a week } \\
\text { One to three times a month } \\
\text { Hardly ever }\end{array}$ & $\begin{array}{l}\text { No/mild activity at least once a } \\
\text { week (reference) } \\
\text { Moderate/vigorous activity at } \\
\text { least once a week }\end{array}$ \\
\hline & Smoking & Single item: Smoker status & $\begin{array}{l}\text { Never } \\
\text { Used to be an occasional smoker } \\
\text { Regular or frequent smoker } \\
\text { Current smoker }\end{array}$ & $\begin{array}{l}\begin{array}{l}\text { Never and past smoker } \\
\text { (reference) }\end{array} \\
\text { Current smoker }\end{array}$ \\
\hline & $\begin{array}{l}\text { Alcohol } \\
\text { consumption }\end{array}$ & $\begin{array}{l}\text { Single item: Frequency of alcohol } \\
\text { consumption over the last } 12 \\
\text { months }\end{array}$ & $\begin{array}{l}\text { Not at all } \\
\text { Once or twice a year } \\
\text { Once every couple of months } \\
\text { Once or twice a month } \\
\text { Once or twice a week } \\
\text { Three or four times a week } \\
\text { Five or six days a week } \\
\text { Almost every day }\end{array}$ & $\begin{array}{l}\text { Less than weekly (reference) } \\
\text { Weekly or more }\end{array}$ \\
\hline \multirow[t]{2}{*}{ Health factors } & $\begin{array}{l}\text { Self-reported } \\
\text { health }\end{array}$ & Single item: Health rating & $\begin{array}{l}\text { Excellent } \\
\text { Very good } \\
\text { Good } \\
\text { Fair } \\
\text { Poor }\end{array}$ & $\begin{array}{l}\text { Fair/Poor (reference) } \\
\text { Good/Very good/Excellent }\end{array}$ \\
\hline & $\begin{array}{l}\text { Functional } \\
\text { limitation }\end{array}$ & $\begin{array}{l}\text { Difficulties with ADL and IADL. } \\
\text { Items combined to form a single } \\
\text { item }\end{array}$ & $\begin{array}{l}\text { ADLs } \\
\text { Dressing } \\
\text { Walking across a room } \\
\text { Bathing or showering } \\
\text { Eating } \\
\text { Getting in or out of bed } \\
\text { Using the toilet } \\
\text { IADLs } \\
\text { Map reading } \\
\text { Preparing a hot meal }\end{array}$ & $\begin{array}{l}\text { No difficulties (reference) } \\
\text { Any difficulties }\end{array}$ \\
\hline
\end{tabular}




\begin{tabular}{|c|c|c|c|c|}
\hline & & & $\begin{array}{l}\text { Shopping for groceries } \\
\text { Making telephone calls } \\
\text { Taking medications } \\
\text { Doing work around the house and garden } \\
\text { Managing money }\end{array}$ & \\
\hline & $\begin{array}{l}\text { Symptoms } \\
\text { preventing } \\
\text { walking } 1 / 4 \text { mile }\end{array}$ & $\begin{array}{l}\text { Items combined to form a single } \\
\text { item }\end{array}$ & $\begin{array}{l}\text { Chest pain } \\
\text { Fatigue/too tired } \\
\text { Shortness of breath } \\
\text { Tremor } \\
\text { Pain in leg or foot } \\
\text { Swelling in leg or foot } \\
\text { Incontinence } \\
\text { Seeing difficulty } \\
\text { Hearing difficulty } \\
\text { Confusion } \\
\text { Difficulty concentrating } \\
\text { Memory problems } \\
\text { Unsteady on feet or balance problems } \\
\text { Lightheaded or dizziness } \\
\text { Fear of falling } \\
\text { Anxiety or fear } \\
\text { Other problem or symptom }\end{array}$ & $\begin{array}{l}\text { No difficulties (reference) } \\
\text { Any difficulties }\end{array}$ \\
\hline \multirow[t]{2}{*}{ Social factors } & $\begin{array}{l}\text { Social group } \\
\text { membership }\end{array}$ & $\begin{array}{l}\text { Current membership of social } \\
\text { groups } \\
\text { Combined to form a single item } \\
(0-8)\end{array}$ & $\begin{array}{l}\text { 1) Political party, trade union or environmental group } \\
\text { 2) Tenants groups, resident groups or neighbourhood } \\
\text { watch } \\
\text { 3) Church or other religious groups } \\
\text { 4) Charitable associations } \\
\text { 5) Education, art or music groups or evening classes } \\
\text { 6) Social club } \\
\text { 7) Sports club, gym or exercise classes } \\
\text { 8) Any other organisations, clubs or societies }\end{array}$ & $\begin{array}{l}\text { <median (low) (reference) } \\
>\text { median (high) }\end{array}$ \\
\hline & Volunteer work & Frequency of volunteer work & $\begin{array}{l}\text { Twice a month or more } \\
\text { About once a month } \\
\text { Every few months } \\
\text { Once or twice a year } \\
\text { Less than once a year }\end{array}$ & $\begin{array}{l}\text { None (reference) } \\
\text { Any }\end{array}$ \\
\hline
\end{tabular}




\begin{tabular}{|c|c|c|c|c|}
\hline & & & Never & \\
\hline \multirow[t]{3}{*}{$\begin{array}{l}\text { Psychological } \\
\text { factors }\end{array}$} & Quality of life & $\begin{array}{l}\text { CASP-19: } \\
\text { Control (e.g. 'I feel free to plan } \\
\text { for the future') ( } 4 \text { items) } \\
\text { Autonomy (e.g. 'I feel that I can } \\
\text { please myself what I do') (5 } \\
\text { items) } \\
\text { Self-realisation (e.g. I feel that life } \\
\text { is full of opportunities') (5 items) } \\
\text { Pleasure (e.g. 'I enjoy the things } \\
\text { that I do') (5 items) }\end{array}$ & $\begin{array}{l}\text { Often } \\
\text { Sometimes } \\
\text { Not often } \\
\text { Never } \\
\text { (Scored 3-0 unless negatively worded where reversed) }\end{array}$ & $\begin{array}{l}<\text { median (low) (reference) } \\
>\text { median (high) }\end{array}$ \\
\hline & Depression & $\begin{array}{l}\text { Eight item version of CES-D } \\
\text { Much of the time during the past } \\
\text { week... } \\
\text {...did you feel depressed? } \\
\text {...did you feel everything you did } \\
\text { was an effort? } \\
\text {...was your sleep restless? } \\
\text {...were you happy? } \\
\text {...did you feel lonely? } \\
\text {...did you enjoy life? } \\
\text {...did you feel sad? } \\
\text {...were you unable to get going? }\end{array}$ & $\begin{array}{l}\text { Yes/No } \\
\text { Responses were summed to give a score between } 0 \text { and } 8 \text { (two } \\
\text { items worded in the positive direction were reverse scored) }\end{array}$ & $\begin{array}{l}\text { No depression (0-3) (reference) } \\
\text { Possible case (4-8) }\end{array}$ \\
\hline & $\begin{array}{l}\text { Cognitive } \\
\text { impairment }\end{array}$ & $\begin{array}{l}\text { Memory test. Immediate and } \\
\text { delayed recall of } 10 \text { words }\end{array}$ & $0-20$ & $\begin{array}{l}<\text { median (low) } \\
\text { (reference) } \\
\text { >median (high) }\end{array}$ \\
\hline \multicolumn{5}{|c|}{$\begin{array}{l}\text { ADL }=\text { Activities of Daily Living } \\
\text { IADL = Instrumental Activities of Daily Living } \\
\text { CASP-19 = Control, Autonomy Self-realisation, Pleasure scale (Hyde et al., 2003) } \\
\text { CES-D = Centre for Epidemiological Studies Depression Scale (Radloff, 1977) }\end{array}$} \\
\hline
\end{tabular}




\begin{tabular}{|c|c|c|c|c|c|c|}
\hline \multicolumn{7}{|c|}{$\begin{array}{l}\text { Supplementary Table 3. Pathways between 'often troubled with pain' } \\
\text { (n=6324) stratified by comorbidity: Direct, indirect and total effects. }\end{array}$} \\
\hline & $\begin{array}{l}\text { Association } \\
\text { between often } \\
\text { troubled with pain } \\
\text { and potential } \\
\text { mediator } \\
\text { Adjusted OR } \\
(95 \% \mathrm{Cl})\end{array}$ & Pathway & $\begin{array}{l}\text { Adjusted HR } \\
\qquad(95 \% \mathrm{Cl})\end{array}$ & $\begin{array}{c}\text { Association } \\
\text { between often } \\
\text { troubled with } \\
\text { pain and } \\
\text { potential } \\
\text { mediator } \\
\text { OR }(95 \% \mathrm{Cl})\end{array}$ & Pathway & $\begin{array}{l}\text { Adjusted HR } \\
(95 \% \mathrm{Cl})\end{array}$ \\
\hline Model & - & $\begin{array}{r}\text { Total effect (no } \\
\text { mediators) }\end{array}$ & $1.26(1.06,1.49)$ & - & $\begin{array}{r}\text { Total effect (no } \\
\text { mediators) }\end{array}$ & $1.19(0.85,1.67)$ \\
\hline $\begin{array}{l}\text { LIFESTYLE FACTORS } \\
\text { Physical activity } \\
\text { none/mild } \\
\text { moderate/vigorous }\end{array}$ & $\begin{array}{l}\text { Reference } \\
0.35(0.30,0.42)\end{array}$ & $\begin{array}{r}\text { Direct } \\
\text { Indirect } \\
\text { Total }\end{array}$ & $\begin{array}{l}1.11(0.95,1.32) \\
1.13(1.09,1.18) \\
1.26(1.05,1.48)\end{array}$ & $\begin{array}{l}\text { Reference } \\
0.39(0.30,0.51)\end{array}$ & $\begin{array}{r}\text { Direct } \\
\text { Indirect } \\
\text { Total }\end{array}$ & $\begin{array}{l}1.08(0.72,1.50) \\
1.14(1.07,1.20) \\
1.23(0.79,1.69) \\
\end{array}$ \\
\hline $\begin{array}{l}\text { Smoking } \\
\text { Non-smoker } \\
\text { Current smoker }\end{array}$ & $\begin{array}{c}\text { Reference } \\
1.18(0.97,1.44)\end{array}$ & $\begin{array}{r}\text { Direct } \\
\text { Indirect } \\
\text { Total }\end{array}$ & $\begin{array}{l}1.24(1.04,1.46) \\
1.01(1.00,1.03) \\
1.26(1.05,1.48)\end{array}$ & $\begin{array}{c}\text { Reference } \\
0.95(0.72,1.25)\end{array}$ & $\begin{array}{r}\text { Direct } \\
\text { Indirect } \\
\text { Total } \\
\end{array}$ & $\begin{array}{l}1.20(0.78,1.70) \\
1.00(0.98,1.01) \\
1.19(0.76,1.68) \\
\end{array}$ \\
\hline $\begin{array}{l}\text { Alcohol consumption } \\
<\text { weekly (low) } \\
>\text { weekly (high) }\end{array}$ & $\begin{array}{l}\text { Reference } \\
0.75(0.65,0.86)\end{array}$ & $\begin{array}{r}\text { Direct } \\
\text { Indirect } \\
\text { Total }\end{array}$ & $\begin{array}{l}1.24(1.03,1.45) \\
1.02(1.00,1.03) \\
1.26(1.05,1.48)\end{array}$ & $\begin{array}{l}\text { Reference } \\
0.69(0.56,0.85)\end{array}$ & $\begin{array}{r}\text { Direct } \\
\text { Indirect } \\
\text { Total }\end{array}$ & $\begin{array}{l}1.20(0.75,1.73) \\
1.00(0.97,1.02) \\
1.19(0.76,1.69) \\
\end{array}$ \\
\hline $\begin{array}{l}\text { HEALTH } \\
\text { Self-reported health } \\
\text { Poor/Fair } \\
\text { Good/Very good/Excellent }\end{array}$ & $\begin{array}{l}\text { Reference } \\
0.23(0.19,0.25)\end{array}$ & $\begin{array}{r}\text { Direct } \\
\text { Indirect } \\
\text { Total }\end{array}$ & $\begin{array}{l}0.96(0.81,1.13) \\
1.29(1.21,1.40) \\
1.25(1.05,1.47)\end{array}$ & $\begin{array}{c}\text { Reference } \\
0.25(0.19,0.33)\end{array}$ & $\begin{array}{r}\text { Direct } \\
\text { Indirect } \\
\text { Total }\end{array}$ & $\begin{array}{l}1.00(0.65,1.39) \\
1.17(1.08,1.31) \\
1.17(0.73,1.69)\end{array}$ \\
\hline
\end{tabular}




\begin{tabular}{|c|c|c|c|c|c|c|}
\hline $\begin{array}{l}\text { Functional limitation } \\
\text { (ADL/IADL difficulties) } \\
\text { No difficulties } \\
\text { Any difficulties }\end{array}$ & $\begin{array}{c}\text { Reference } \\
5.76(4.92,6.76)\end{array}$ & $\begin{array}{r}\text { Direct } \\
\text { Indirect } \\
\text { Total }\end{array}$ & $\begin{array}{l}1.00(0.82,1.17) \\
1.25(1.16,1.34) \\
1.25(1.05,1.46)\end{array}$ & $\begin{array}{c}\text { Reference } \\
4.67(3.57,6.11)\end{array}$ & $\begin{array}{r}\text { Direct } \\
\text { Indirect } \\
\text { Total }\end{array}$ & $\begin{array}{l}0.95(0.59,1.34) \\
1.27(1.16,1.43) \\
1.20(0.76,1.75)\end{array}$ \\
\hline $\begin{array}{l}\text { Symptoms preventing walking } 1 / 4 \text { mile } \\
\text { No symptoms } \\
\text { Any symptoms }\end{array}$ & $\begin{array}{c}\text { Reference } \\
6.83(5.78,8.10)\end{array}$ & $\begin{array}{r}\text { Direct } \\
\text { Indirect } \\
\text { Total }\end{array}$ & $\begin{array}{l}0.86(0.72,1.06) \\
1.45(1.34,1.55) \\
1.25(1.04,1.47)\end{array}$ & $\begin{array}{c}\text { Reference } \\
6.39(4.70,8.73)\end{array}$ & $\begin{array}{r}\text { Direct } \\
\text { Indirect } \\
\text { Total }\end{array}$ & $\begin{array}{l}0.95(0.58,1.36) \\
1.21(1.08,1.36) \\
1.15(0.76,1.64)\end{array}$ \\
\hline $\begin{array}{l}\text { SOCIAL FACTORS } \\
\text { Social group membership } \\
0-1 \text { group } \\
2 \text { or more groups }\end{array}$ & $\begin{array}{c}\text { Reference } \\
\mathbf{0 . 8 0}(\mathbf{0 . 6 9 , 0 . 9 2 )}\end{array}$ & $\begin{array}{r}\text { Direct } \\
\text { Indirect } \\
\text { Total }\end{array}$ & $\begin{array}{l}1.24(1.04,1.46) \\
1.01(1.00,1.02) \\
1.26(1.05,1.48) \\
\end{array}$ & $\begin{array}{c}\text { Reference } \\
0.94(0.77,1.15)\end{array}$ & $\begin{array}{r}\text { Direct } \\
\text { Indirect } \\
\text { Total }\end{array}$ & $\begin{array}{l}1.19(0.76,1.66) \\
1.00(0.99,1.02) \\
1.19(0.76,1.68) \\
\end{array}$ \\
\hline $\begin{array}{l}\text { Volunteer work } \\
\text { None } \\
\text { Any }\end{array}$ & $\begin{array}{c}\text { Reference } \\
\mathbf{0 . 8 0}(0.69,0.93)\end{array}$ & $\begin{array}{r}\text { Direct } \\
\text { Indirect } \\
\text { Total }\end{array}$ & $\begin{array}{l}1.24(1.04,1.45) \\
1.01(1.00,1.02) \\
1.26(1.05,1.48)\end{array}$ & $\begin{array}{c}\text { Reference } \\
0.98(0.79,1.21)\end{array}$ & $\begin{array}{r}\text { Direct } \\
\text { Indirect } \\
\text { Total }\end{array}$ & $\begin{array}{l}1.19(0.76,1.66) \\
1.00(0.99,1.02) \\
1.19(0.76,1.67) \\
\end{array}$ \\
\hline $\begin{array}{l}\text { PSYCHOLOGICAL FACTORS } \\
\text { Quality of life } \\
\text { < median (low) } \\
\text { >median (high) } \\
\text { Control } \\
<\text { median (low) } \\
\text { >median (high) } \\
\text { Autonomy } \\
<\text { median(low) } \\
>\text { median(high) } \\
\text { Pleasure } \\
<\text { median (low) } \\
\text { >median (high) } \\
\text { Self-realisation } \\
<\text { median (low) } \\
>\text { median (high) }\end{array}$ & $\begin{array}{c}\text { Reference } \\
0.37(0.32,0.43) \\
\text { Reference } \\
0.48(0.41,0.56) \\
\\
\text { Reference } \\
0.37(0.32,0.43) \\
\\
\text { Reference } \\
\mathbf{0 . 6 6}(0.57,0.75) \\
\\
\text { Reference } \\
\mathbf{0 . 4 9}(0.42,0.56)\end{array}$ & $\begin{array}{r}\text { Direct } \\
\text { Indirect } \\
\text { Total } \\
\\
\text { Direct } \\
\text { Indirect } \\
\text { Total } \\
\text { Direct } \\
\text { Indirect } \\
\text { Total } \\
\text { Direct } \\
\text { Indirect } \\
\text { Total } \\
\text { Direct } \\
\text { Indirect } \\
\text { Total }\end{array}$ & $\begin{array}{l}1.15(0.97,1.39) \\
1.09(1.05,1.13) \\
1.25(1.05,1.47) \\
1.19(1.00,1.41) \\
1.05(1.03,1.08) \\
1.26(1.05,1.47) \\
1.19(1.01,1.42) \\
1.05(1.02,1.09) \\
1.26(1.06,1.48) \\
1.25(1.05,1.47) \\
1.01(0.99,1.02) \\
1.26(1.05,1.48) \\
1.20(1.00,1.43) \\
1.04(1.02,1.07) \\
1.26(1.05,1.48)\end{array}$ & $\begin{array}{c}\text { Reference } \\
0.56(0.46,0.68) \\
\text { Reference } \\
0.53(0.44,0.65) \\
\\
\text { Reference } \\
\mathbf{0 . 6 4}(0.53,0.78) \\
\\
\text { Reference } \\
\mathbf{0 . 6 1}(0.50,0.75)\end{array}$ & $\begin{array}{r}\text { Direct } \\
\text { Indirect } \\
\text { Total } \\
\\
\text { Direct } \\
\text { Indirect } \\
\text { Total } \\
\text { Direct } \\
\text { Indirect } \\
\text { Total } \\
\text { Direct } \\
\text { Indirect } \\
\text { Total } \\
\text { Direct } \\
\text { Indirect } \\
\text { Total } \\
\end{array}$ & $\begin{array}{l}1.10(0.69,1.52) \\
1.09(1.04,1.15) \\
1.20(0.75,1.70) \\
\\
1.15(0.72,1.62) \\
1.03(1.00,1.07) \\
1.18(0.74,1.68) \\
\\
1.12(0.71,1.56) \\
1.06(1.02,1.11) \\
1.20(0.76,1.69) \\
1.14(0.73,1.61) \\
1.06(1.02,1.10) \\
1.20(0.76,1.72) \\
1.16(0.73,1.60) \\
1.05(1.02,1.08) \\
1.21(0.77,1.70) \\
\end{array}$ \\
\hline Depression & & Direct & $1.16(0.96,1.36)$ & & Direct & $1.14(0.74,1.57)$ \\
\hline
\end{tabular}




\begin{tabular}{|c|c|c|c|c|c|c|}
\hline $\begin{array}{l}\text { Not depressed (CESD score) }<4 \\
\text { Depressed }>4\end{array}$ & $\begin{array}{c}\text { Reference } \\
2.58(2.23,2.99)\end{array}$ & $\begin{array}{r}\text { Indirect } \\
\text { Total }\end{array}$ & $\begin{array}{l}1.08(1.03,1.12) \\
1.25(1.05,1.46)\end{array}$ & $\begin{array}{c}\text { Reference } \\
1.90(1.51,2.38)\end{array}$ & $\begin{array}{r}\text { Indirect } \\
\text { Total }\end{array}$ & $\begin{array}{l}1.05(1.01,1.10) \\
1.20(0.77,1.68)\end{array}$ \\
\hline $\begin{array}{l}\text { Cognitive impairment } \\
<\text { median (low ability) } \\
>\text { median (high ability) }\end{array}$ & $\begin{array}{c}\text { Reference } \\
0.84(0.73,0.97)\end{array}$ & $\begin{array}{r}\text { Direct } \\
\text { Indirect } \\
\text { Total }\end{array}$ & $\begin{array}{l}1.25(1.05,1.47) \\
1.01(1.00,1.02) \\
1.26(1.05,1.48)\end{array}$ & $\begin{array}{c}\text { Reference } \\
0.80(0.65,0.98)\end{array}$ & $\begin{array}{r}\text { Direct } \\
\text { Indirect } \\
\text { Total }\end{array}$ & $\begin{array}{l}1.18(0.76,1.68) \\
1.02(1.00,1.04) \\
1.20(0.76,1.70) \\
\end{array}$ \\
\hline $\begin{array}{l}\text { All models adjusted for age, sex, } \\
\mathrm{OR}=\text { Odds ratio } \\
\mathrm{HR}=\text { Hazard ratio } \\
\mathrm{Cl}=\text { Confidence Intervals } \\
\text { Significant associations between }\end{array}$ & $\begin{array}{l}\text { ind wealth } \\
\text { nd mediator and in }\end{array}$ & 161 & & & & \\
\hline
\end{tabular}

